\title{
Conformations of calix[4]arenes - an investigation based on CSD data. Part I. Cone conformers of methylene- and heteroatom-bridged calix[4]arenes
}

\begin{abstract}
Conformations of calix[4]arenes with methylene and heteroatom bridges from the Cambridge Structural Database (CSD) were investigated with the help of the previously introduced parameters $\alpha, \beta$ and $\delta$. The usefulness of these parameters in describing the conformations of the scaffolds of the above mentioned compounds was demonstrated. The dependence of the values of these parameters on inter- and/or intramolecular interactions present in the structure was investigated in order to discover how the geometry of the calix[4]arene moiety depends on the above listed effects. Structures with $\mathrm{C}_{4 \mathrm{v}}$ symmetry in the cone group have both $\beta$ and $\delta$ close to $0^{\circ}$. With deformation of the calix[4]arene symmetry towards $C_{2 v}$ (flattened cone structures), the $\beta$ parameter increases. Deformation towards $C_{s}$ symmetry is best reflected by increase of the parameter $\delta$. Parameter $\alpha$ reflects the degree of 'opening' of the calix[4]arene cavity; structures with four OH groups at the lower rim tend to have lower $\alpha$ and therefore more open structure.
\end{abstract}

Keywords: calix[4]arene, macromolecules, conformation, torsion angle, distorsion parameter, intramolecular interactions.

\section{Introduction}

Calix[4]arenes are a class of macrocyclic compounds which has recently attracted a lot of attention because of their possible utilization in many areas of research and industry. Because of their potential, the chemistry of calixarenes has in the last few years developed into a wide and well-explored area [1]. These macrocycles have been used principally as spacers bearing functional groups in a well-defined arrangement, allowing their desired cooperation [2].

The utilization of calix[4]arenes as molecular platforms possesses a few advantages. First, the synthesis of these macrocycles can be easily accomplished by a well-known procedure in good yields. The size of the macrocycle can be successfully controlled by the reaction conditions [3]. The starting materials (p-tert.butylphenol and formaldehyde) are inexpensive and common. Calix[4]arenes can be easily modified both on their upper and lower rim [3], which allows their chemical and physical properties to change as required. Finally, the four possible conformations of the calix[4]arene macrocycle, easily immobilized by lower rim substitution [2], are the main reason for the advantage of using calix[4]arenes as molecular platforms.

Recently, calix[4]arenes with heteroatom bridge groups have been synthesized [4]. These compounds contain a heteroatom $(\mathrm{S}, \mathrm{O})$ or a functional group based on a heteroatom $\left(\mathrm{SO}, \mathrm{SO}_{2}, \mathrm{NR}, \mathrm{SiR}_{2}\right)$ instead of the methylene bridge, which often results in higher conformational flexibility [5].

The conformation and symmetry of the calix[4]arene molecule is important for its function as a spacer bearing substituents in a defined arrangement, which allows their interaction, interaction with cations, anions or neutral molecules, cooperation in ion pair binding etc. [2,6]. The rigidity or flexibility of the calix[4]arene base skeleton is an important factor controlling the distances among functional groups on the calix[4]arene upper and/or lower rim. Another important factor is the rigidity or flexibility of the substituents on the calix[4]arene skeleton. The rigidity of the calix[4]arene skeleton can be achieved by bridging the upper or lower rim of the calix[4]arene molecule, effectively locking its movements [2]. Furthermore, the conformation of the calix[4]arene platform can be influenced by the interactions of its hydrophobic cavity or aromatic rings with cations or neutral molecules by the means of cation- $\pi$ interactions, $\pi, \pi$-interactions or Van der Waals interactions. The substituents on the upper or lower rim may also participate in shaping of the calix[4]arene molecule. The possible interactions (beside the above mentioned ones) may involve inter- or intramolecular hydrogen bonding, electrostatic interactions, donor-acceptor interactions (cation complexes or Lewis acid-base pairing) and sterical hindrance. In conclusion, the final shape of the calix[4]arene platform results from the combination of all these effects. Effective control of the stereochemistry of the calix[4]arene platform (e.g. fine tuning of the geometry of these molecules) is essential for its utilization in functional molecules such as allosteric receptors possessing both positive and negative allosteric effect and molecular machines [2]. 
The four possible conformations for calix[4]arenes (both methylene- and heteroatom-bridged) [1] are depicted in Figure 1.

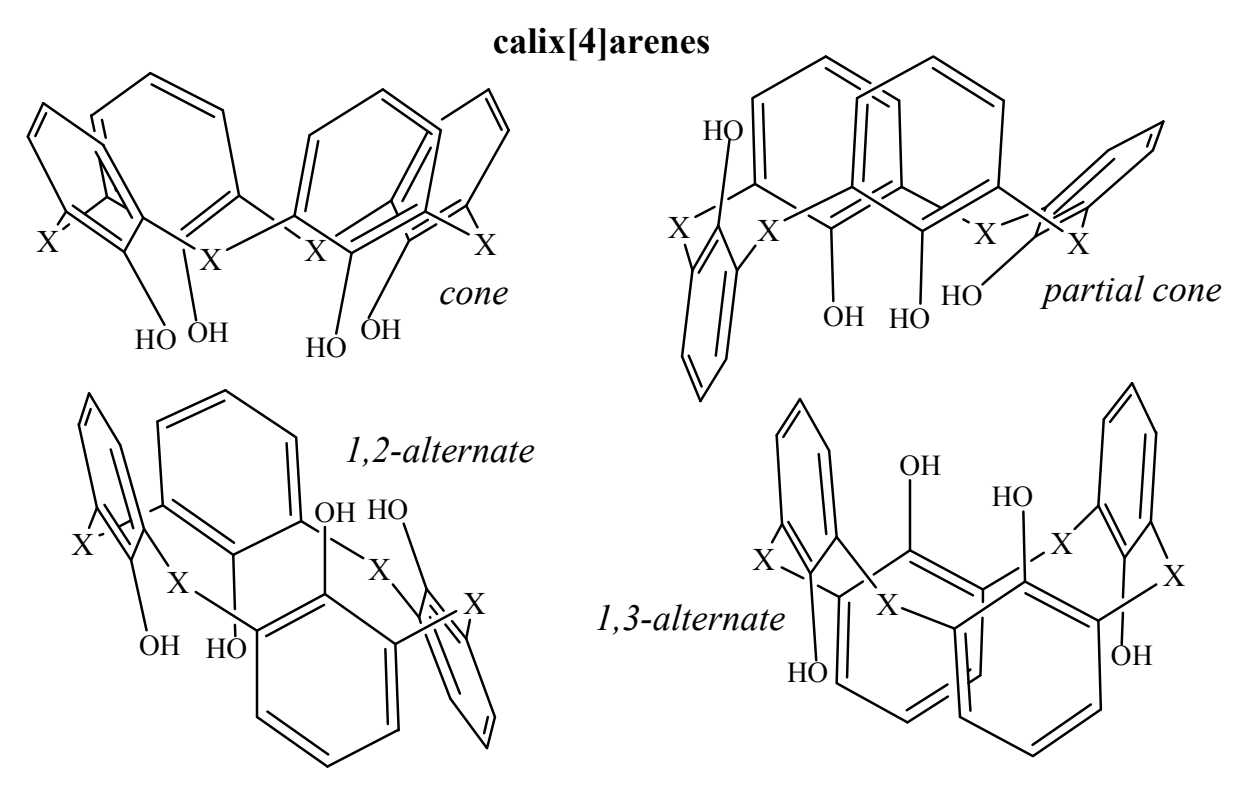

Figure 1. The four basic conformations of calix[4] arenes $\left(\mathrm{X} \ldots \mathrm{CH}_{2}\right.$ or heteroatom/heterogroup)

To elucidate the influence of the substitution on the upper and lower rim of the calix[4]arene and interor intramolecular interactions on the conformation of the calix[4]arene molecule, we decided for the Cambridge Structural Database [7] as the largest source of information (more than 1,800 of calix[4]arene structures). The conformation of the calix[4]arene molecules and inter- or intramolecular interactions of these compounds can be easily determined from the crystal structure data. Nevertheless, this information might not fully correspond to the conformational behavior of the calix[4]arene molecules in solution.

The conformation of the calix[4]arene base frame (e.g. hydrocarbon skeleton without upper rim and lower rim substituents) can be fully described by the values of torsion angles at the $\mathrm{C}_{\text {arom }}-\mathrm{C}_{\text {bridge }}$ bonds. In the case of calix[4]arenes, the relevant torsion angles visible on Figure 2 are the angles C28-C1-C2-C3, C24-C1$\mathrm{C} 2-\mathrm{C} 3, \mathrm{C} 1-\mathrm{C} 2-\mathrm{C} 3-\mathrm{C} 4$ and $\mathrm{C} 1-\mathrm{C} 2-\mathrm{C} 3-\mathrm{C} 25$. There are obviously two torsion angles at each bond $\mathrm{C}_{\text {arom }}-\mathrm{C}_{\text {bridge}}$, so there are altogether 16 (sexteen!!) relevant torsion angles to describe the conformation of the calix[4]arene (or backbone of heteroatom-bridged one). Similar approach based torsion angles on has been recently used by Schneider B. et al. to describe the conformation of the backbone of nucleic acids [8].

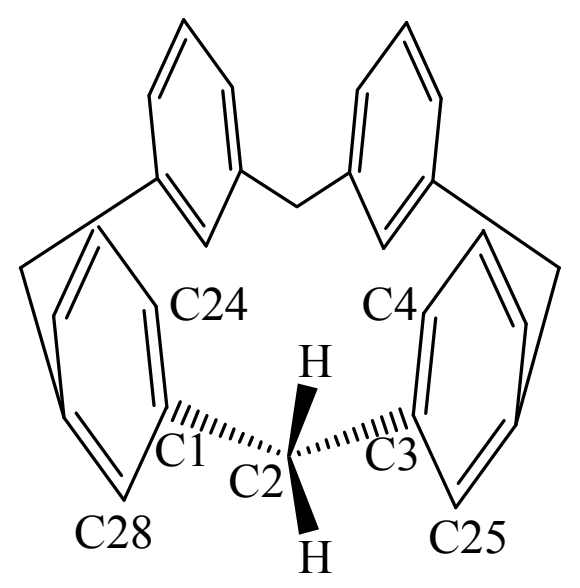

Figure 2. Torsion angles at the calix[4]arene skeleton

However, having sixteen parameters to describe the calix[4]arene conformation is rather tedious and inconvenient. There is a need for reduction of the number of relevant parameters. The most convenient way to achieve this seems to be the approach published by Arnaud-Neu F. et al. [9], using the plane of the four 
bridge carbon atoms as a reference plane and the values of the angles of the four phenyl rings to this reference plane as parameters to describe the calix[4]arene conformation. A variety of other geometrical parameters can be calculated (e.g. the distances between the oxygen or carbon atoms on the lower or upper rim, the angles of the planes of the phenyl rings etc.), but none seem to be such natural and convenient as the previously mentioned one [9].

Therefore, we have decided to describe the calix[4]arene geometry by the defining of a reference plane to which the angles of the four phenyl rings are related. This reference plane is the plane of the four bridge groups [9] (for the vast majority of structures from CSD [7], the deviations of the bridge atoms from this plane are below $0.1 \AA$ ). The angles of the phenyl rings $\left(\alpha_{i}, i=1-4\right)$ are calculated in the scale $0-360^{\circ}$ (see Fig. 3 ).

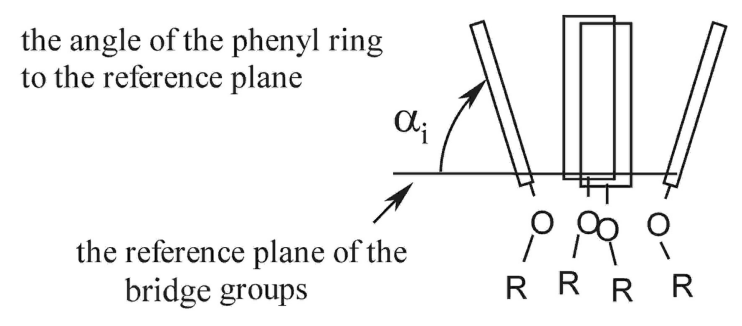

Figure 3. The definition of the phenyl ring angles $\alpha_{\mathrm{i}}$

The previous sixteen torsion angle parameters have been successfully reduced by this approach to four parameters $\alpha_{1}-\alpha_{4}$. However, the assignment of these four parameters is not unambiguous and depends on the numbering of the calix[4]arene base frame; problems such as which calix[4]arene phenyl ring will be assigned as $\alpha_{1}$, if the following numbering will run clockwise or counterclockwise etc. have to be solved. Moreover, four parameters form a four-dimensional space, which is very difficult to imagine and work with. It would be therefore more convenient to further reduce the number of parameters from four to three, since $3 \mathrm{D}$ space is much easier to describe. To achieve these two objectives, the next step in the description of the calix[4]arene conformations is the definition of geometrical parameters $\boldsymbol{\alpha}, \boldsymbol{\beta}, \boldsymbol{\delta}[10]$ :

$$
\begin{aligned}
& \boldsymbol{\alpha}=1 / 4^{*}\left(\alpha_{1}+\alpha_{2}+\alpha_{3}+\alpha_{4}\right) ; \\
& \boldsymbol{\beta}=\left|\left(\alpha_{1}+\alpha_{3}\right)-\left(\alpha_{2}+\alpha_{4}\right)\right| ; \\
& \boldsymbol{\delta}=\left|\alpha_{1}-\alpha_{3}\right|+\left|\alpha_{2}-\alpha_{4}\right| .
\end{aligned}
$$

The parameter $\alpha$ is the average value of the phenyl ring angles $\alpha_{1}-\alpha_{4}$ (numbering reflects the order of the phenyl rings in the calix[4]arene molecule, e.g. $\alpha_{1}, \alpha_{2}$ corresponds to adjacent rings, $\alpha_{1}$, $\alpha_{3}$ to opposite rings etc.). The parameter $\boldsymbol{\beta}$ (for calix[4]arenes in the cone conformation) reflects the distortion of the calix[4]arene molecule towards $\mathrm{C}_{2 \mathrm{v}}$ symmetry. Finally, $\boldsymbol{\delta}$ reflects the distortion towards $\mathrm{C}_{\mathrm{s}}$ symmetry (again, for calix[4]arenes in the cone conformation). Some examples of model values $\alpha_{1}-\alpha_{4}$ and of parameters $\alpha, \beta$ and $\boldsymbol{\delta}$ for cone, partial cone, 1,2-alternate and 1,3-alternate calix[4]arenes are shown in Fig. S-1 in the Supplementary Materials.

It is necessary to emphasize that the parameters $\alpha, \beta, \delta$ are independent on the 'order' of the calix[4]arene rings with respect to which of them the $\alpha_{1}$ angle is assigned (they do not depend on the numbering scheme of the molecule). However, the value of the $\alpha$ parameter in the case of 1,2- and 1,3-alternate calix[4]arenes depends on the assignment of the 'positive' and 'negative' angles. The dependence of the parameter $\alpha$ on this assignment can be demonstrated on the absolute values of the sum of the 'positive' and the sum of the 'negative' angles (the 'negative' angles are taken as $\alpha_{\mathrm{i}}-360^{\circ}$ for this calculation). If for a given molecule the absolute value of the sum of the 'negative' angles is greater than the sum of the 'positive' ones, we get $\alpha$ lower than $180^{\circ}$; in the case of opposite assignment, $\alpha$ is greater than $180^{\circ}$. Since these numbers differ from $180^{\circ}$ by the same value (added to or subtracted from $180^{\circ}$ ), we decided to define the 'positive' angles as those which sum is in absolute value greater than the absolute value of the sum of the other two. Therefore, all $\alpha$ values for 1,2- and 1,3-alternate calix[4]arenes are equal to or greater than $180^{\circ}$ according to this convention". The calculation of the parameter $\alpha$ in the case of cone and partial cone calix[4]arenes is unambiguous since there is no 'negative' angle in the case of cone and only one in the case of partial cone calix[4]arenes.

\footnotetext{
${ }^{*}$ In our previous publications [10], we did not always abide by this convention!!
} 
Thus, the parameters $\boldsymbol{\alpha}, \boldsymbol{\beta}, \boldsymbol{\delta}$ reflect the conformation and symmetry of the calix[4]-arene scaffold and can be used for the description of the geometry of these molecules.

The conformations of the larger calixarenes are impossible to describe by similar parameters because of their greater conformational flexibility and therefore significant deviations of methylene bridge atoms from the reference plane - average deviation $0.0000 \AA$ in the case of p-tert.butylcalix[4]arene (structure BHPMYC [7]), $0.1911 \AA$ in the case of $p$-tert.butylcalix[5] arene (structure LAZZAN [7]), $1.5261 \AA$ in the case of p-tert.butyl-calix[6]arene (structure KAHJUY [7]), $1.6504 \AA$ in the case of $p$-tert.butylcalix[7] arene (structure YACHIT [7]) and $1.5704 \AA$ in the case of $p$-tert.butylcalix[8]arene (structure DOVHIF [7]), respectively. The larger calixarenes were therefore not included in this investigation.

\section{Results and discussion}

The number of hits obtained from CSD [7] including the distribution of calix[4]arenes according to their conformation is shown in Table 1. The total of 1,826 hits was obtained from [7] and their conformation was determined. Three hits were impossible to classify and are included separately in the table. Table 1 also shows the number of crystallographically independent molecules in complete cif files, number of incomplete cif files (atom coordinates not included in the file) and the sums of relevant data in all groups. The sum of complete and incomplete cif files in the described groups does not correspond to the total number because some structures belong to more than one group.

T a b l e 1

The distribution of calix[4]arenes from [7] according to their conformations

\begin{tabular}{|c|c|c|c|c|c|c|c|}
\hline Type & Conformation & $\begin{array}{l}\text { Number of com- } \\
\text { plete cif files }\end{array}$ & $\%$ & $\begin{array}{c}\text { Number of } \\
\text { independent } \\
\text { molecules }\end{array}$ & $\%$ & $\begin{array}{l}\text { Number of in- } \\
\text { complete cif files }\end{array}$ & $\%$ \\
\hline \multirow{6}{*}{$\begin{array}{l}\mathrm{CH}_{2} \text {-bridged } \\
\text { calix[4]arene }\end{array}$} & cone & 1182 & 64.73 & 1442 & 70.07 & 87 & - \\
\hline & partial cone & 93 & 5.09 & 106 & 5.15 & 3 & - \\
\hline & 1,2-alternate & 56 & 3.07 & 65 & 3.16 & 5 & - \\
\hline & 1,3-alternate & 171 & 9.36 & 192 & 9.33 & 13 & - \\
\hline & not determined & - & - & - & - & 2 & - \\
\hline & total & 1500 & 82.15 & 1805 & 87.71 & 110 & 6.02 \\
\hline \multirow{6}{*}{$\begin{array}{l}\text { Heteroatom- } \\
\text { bridged } \\
\text { calix[4]arene }\end{array}$} & cone & 112 & 6.13 & 137 & 6.66 & 3 & - \\
\hline & partial cone & 11 & 0.60 & 14 & 0.68 & 1 & - \\
\hline & 1,2-alternate & 26 & 1.42 & 29 & 1.41 & 3 & - \\
\hline & 1,3-alternate & 57 & 3.12 & 73 & 3.55 & 6 & - \\
\hline & not determined & - & - & - & - & 1 & - \\
\hline & total & 204 & 11.17 & 253 & 12.29 & 14 & 0.77 \\
\hline \multirow[t]{2}{*}{ Total } & & 1702 & 93.21 & 2058 & 100 & 124 & 6.79 \\
\hline & total & 1826 & 100 & & & & \\
\hline
\end{tabular}

The group of calix[4]arenes with methylene bridges is significantly larger than the groups of calix[4]arenes with heteroatom bridges (see Table 1). There are altogether 1610 cif files belonging to this group ( $88 \%$ from the total of 1,826 cif files in [7]); the number of 218 cif files for calix[4]arenes with heteroatom bridges amounts to about $12 \%$. Therefore, almost nine tenths of all calix[4]arene structures in [7] belong to calix[4]arenes with methylene bridges.

In the number of independent molecules, 1805 hits belong to calix[4]arenes with methylene bridges (88\% of all 2058 hits) and 253 hits to calix[4]arenes with methylene bridges (12\%).

From these numbers, it is obvious that cone calix[4]arenes with methylene bridges are the group which has attracted the most interest in research. Calix[4]arenes with heteroatom bridges are not so numerous probably because these molecules have emerged relatively recently compared to the methylene-bridged group; moreover, there are difficulties in their selective substitution, their greater conformational flexibility and diminished stability towards aggressive chemical agents [5].

The above mentioned effect of substitution in the group of methylene- and heteroatom-bridged calix[4]arenes is given in Tables 2 and 3. Structures where conformation was not determined are not included. Duplicite cif files (structures belonging to more than one group) are included in all relevant groups. 
Table 2

Distribution of substitution patterns of methylene-bridged calix[4]arenes

\begin{tabular}{|c|c|c|c|c|c|}
\hline Conformation & Type & Number of cif files & $\%$ & Number of independent molecules & $\%$ \\
\hline \multirow{2}{*}{ Cone } & \multirow{2}{*}{$\begin{array}{c}\text { symmetrically } \\
\text { tetrasubstituted } \\
\text { other }\end{array}$} & 607 & 47.5 & 701 & 48.6 \\
\hline & & 672 & 52.5 & 741 & 51.4 \\
\hline \multirow{2}{*}{ Partial cone } & \multirow{2}{*}{$\begin{array}{c}\text { symmetrically } \\
\text { tetrasubstituted } \\
\text { other }\end{array}$} & 24 & 25.1 & 27 & 25.5 \\
\hline & & 72 & 74.9 & 79 & 74.5 \\
\hline \multirow{2}{*}{ 1,2-Alternate } & \multirow{2}{*}{$\begin{array}{c}\text { symmetrically } \\
\text { tetrasubstituted } \\
\text { other }\end{array}$} & 16 & 26.2 & 17 & 26.1 \\
\hline & & 45 & 73.8 & 48 & 73.9 \\
\hline \multirow{2}{*}{ 1,3-Alternate } & \multirow{2}{*}{$\begin{array}{c}\text { symmetrically } \\
\text { tetrasubstituted } \\
\text { other }\end{array}$} & 42 & 22.8 & 43 & 22.4 \\
\hline & & 142 & 77.2 & 149 & 77.6 \\
\hline \multirow[t]{2}{*}{ Total } & \multirow{2}{*}{$\begin{array}{c}\text { symmetrically } \\
\text { tetrasubstituted } \\
\text { other }\end{array}$} & 689 & 42.5 & 788 & 43.7 \\
\hline & & 931 & 57.5 & 1017 & 56.3 \\
\hline
\end{tabular}

From Table 2, it can be seen that in the group of cone methylene-bridged structures there is almost $50 \%$ of symmetrically tetrasubstituted structures whereas in other conformations the percentage of symmetrically tetrasubstituted structures is about $25 \%$.

However, the underlying principle in the group of heteroatom-bridged calix[4]arenes is the presence of a relatively large number of symmetrically tetrasubstituted structures (Table 3); even in the case of partial cone and 1,2-alternate conformers (compared to their methylene-bridged counterparts). The reason behind this observation is probably that the synthetic methods for selective substitution of heteroatom-bridged calix[4]arenes are less developed than in the case of methylene-bridged calix[4]arenes (for selective substitution of heteroatom-bridged calix[4]arenes, see e.g. [11]).

Ta a le 3

Distribution of substitution patterns of heteroatom-bridged calix[4]arenes

\begin{tabular}{|c|c|c|c|c|c|}
\hline Conformation & Type & Number of cif files & $\%$ & Number of independent molecules & $\%$ \\
\hline \multirow{3}{*}{ Cone } & $\begin{array}{c}\text { symmetrically } \\
\text { tetrasubstituted } \\
\text { other }\end{array}$ & 89 & 77.4 & 106 & 77.4 \\
& 26 & 22.6 & 31 & 22.6 \\
\hline \multirow{3}{*}{ Partial cone } & $\begin{array}{c}\text { symmetrically } \\
\text { tetrasubstituted } \\
\text { other }\end{array}$ & 9 & 75.0 & 9 & 64.3 \\
& $\begin{array}{c}\text { symmetrically } \\
\text { tetrasubstituted } \\
\text { other }\end{array}$ & 23 & 79.3 & 5 & 35.7 \\
\hline \multirow{3}{*}{ 1,3-Alternate } & $\begin{array}{c}\text { symmetrically } \\
\text { tetrasubstituted } \\
\text { other }\end{array}$ & 40 & 63.5 & 23 & 79.3 \\
& $\begin{array}{c}\text { symmetrically } \\
\text { Total }\end{array}$ & 161 & 73.5 & 47 & 20.7 \\
& $\begin{array}{c}\text { tetrasubstituted } \\
\text { other }\end{array}$ & 58 & 26.5 & 26 & 64.4 \\
& & & 68 & 35.6 \\
\hline
\end{tabular}

The parameters $\alpha, \beta, \delta$ were designed to reflect the conformation of the calix[4]arene molecules (see Fig. 1); each calix[4]arene molecule represents a dot in a 3D space defined by parameters $\boldsymbol{\alpha}, \boldsymbol{\beta}, \boldsymbol{\delta}$. The 3D depiction of parameters $\boldsymbol{\alpha}, \boldsymbol{\beta}, \boldsymbol{\delta}$ for all calix[4]arenes from [7] is given in Figure 4. 


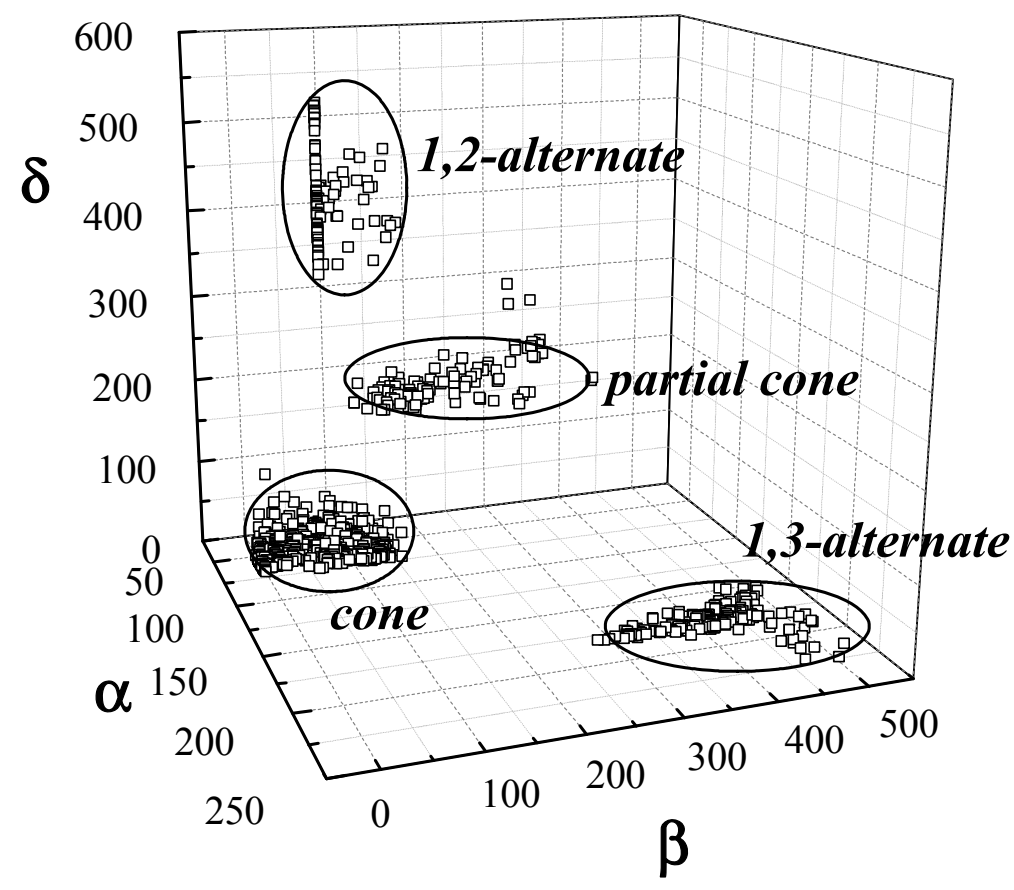

Figure 4. 3D plot of parameters $\boldsymbol{\alpha}, \boldsymbol{\beta}, \boldsymbol{\delta}$

From the above plot, it is obvious that $2 \mathrm{D} \beta-\delta$ plots showing the deformation of the calix[4]arene scaffold are the most informative ones. The $\beta-\delta$ plot is illustrated on the group of calix[4]arenes with $\mathrm{CH}_{2}$ bridges (Fig. 5), calix[4]arenes with heteroatom bridges (Fig. 6) and all these structures (Fig. 7).

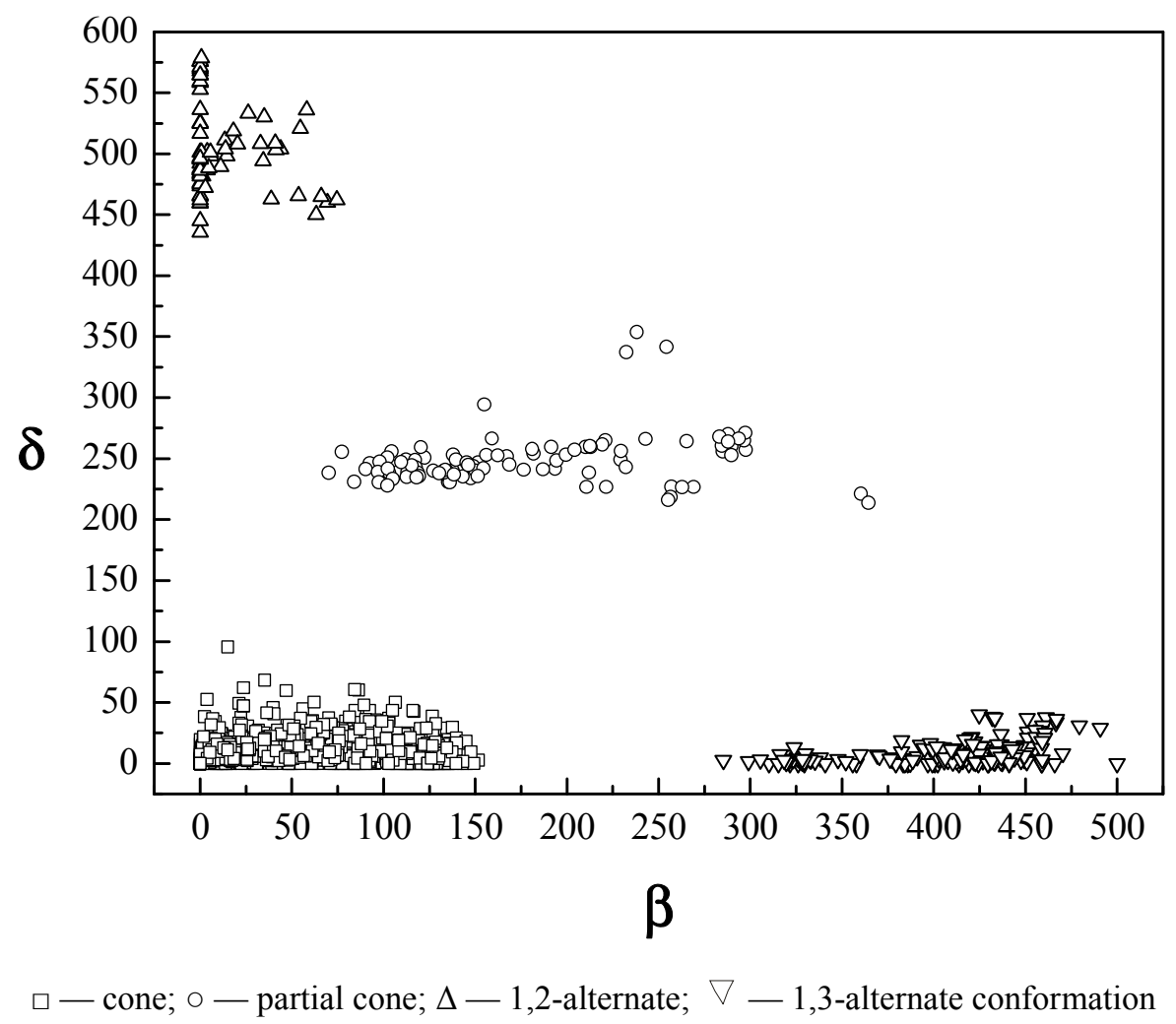

Figure 5. The distribution of the $\beta, \delta$ values in the group of calix[4]arenes with methylene bridges from [7] 


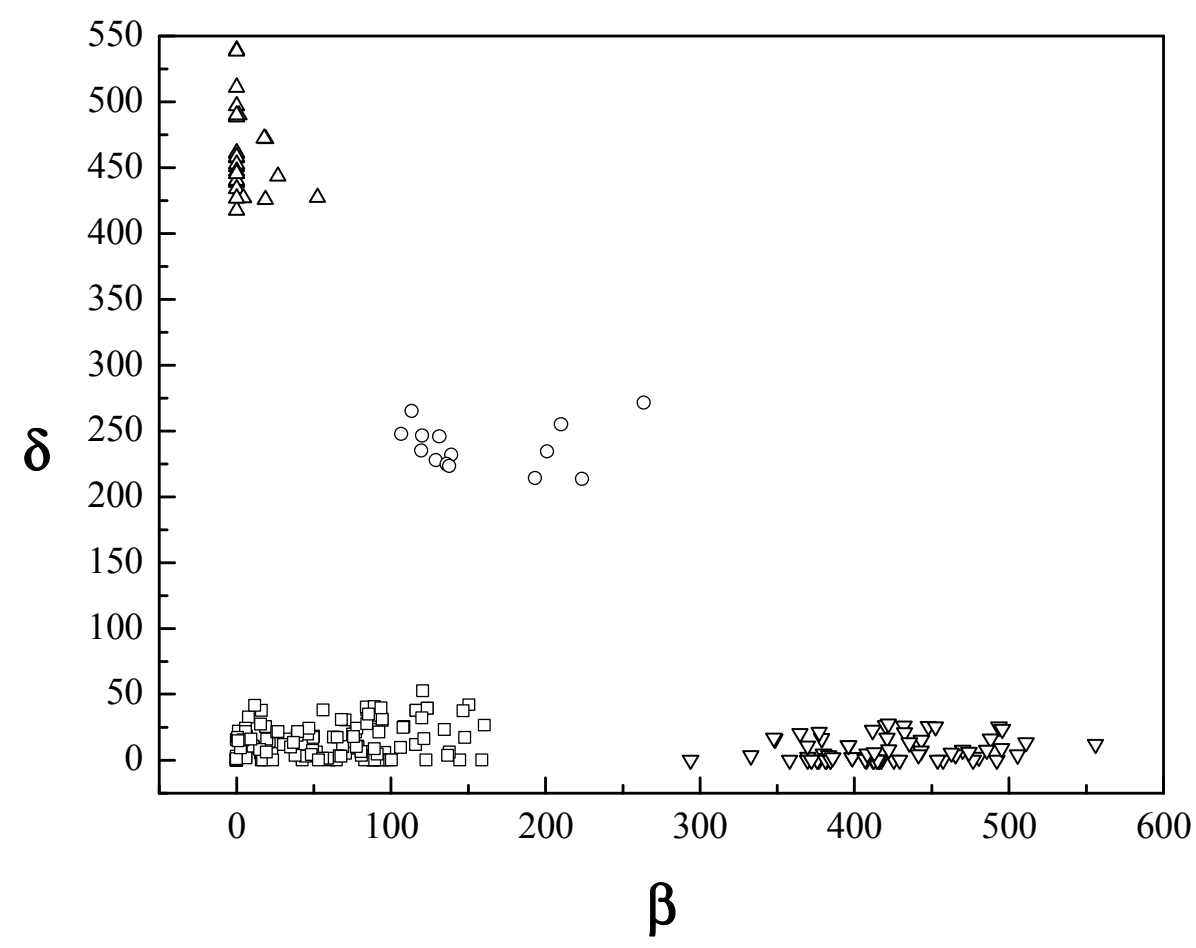

$\square-$ cone; $\circ-$ partial cone; $\Delta-1,2$-alternate; $\nabla-1,3$-alternate conformation

Figure 6. The distribution of the $\beta, \delta$ values in the group of calix[4]arenes with heteroatom bridges from [7]

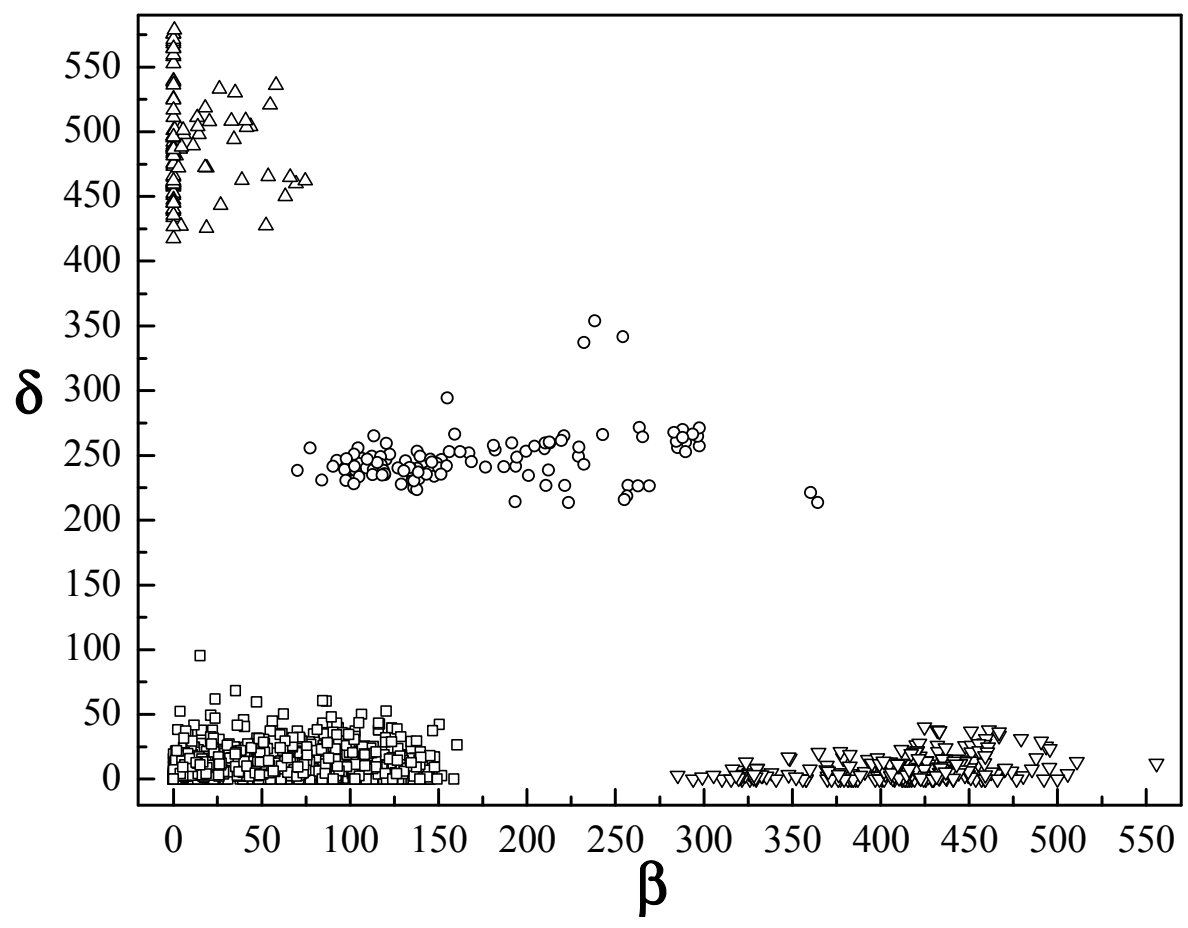

$\square-$ cone; $\circ-$ partial cone; $\Delta-1,2$-alternate; $\nabla-1,3$-alternate conformation

Figure 7. The distribution of the $\beta, \delta$ values in all previously mentioned structures from [7]

The average values of parameters $\alpha, \beta, \delta$ and their standard deviations (in ${ }^{\circ}$ ) in the respective groups (position of data-clusters) of four conformers (see Table 4) give us useful information, too. They reflect the rigidity or flexibility of the calix[4]arene skeleton as well as the distribution of the parameters $\boldsymbol{\alpha}, \boldsymbol{\beta}, \boldsymbol{\delta}$. 
The average values of parameters $\alpha, \beta, \delta$ and their standard deviations (in ${ }^{\circ}$ )

\begin{tabular}{|c|c|c|c|c|c|}
\hline Type of bridge & Conformation & Parameter & Average value AV & Standard deviation SD & $\mathrm{SD} / \mathrm{AV}$ \\
\hline \multirow{12}{*}{$\mathrm{CH}_{2}$} & \multirow{3}{*}{ cone } & $\alpha$ & 59.19 & 6.46 & 0.11 \\
\hline & & $\beta$ & 55.61 & 43.03 & 0.77 \\
\hline & & $\delta$ & 9.29 & 9.59 & 1.03 \\
\hline & \multirow{3}{*}{ partial cone } & $\alpha$ & 119.37 & 7.36 & 0.06 \\
\hline & & $\beta$ & 172.99 & 69.20 & 0.40 \\
\hline & & $\delta$ & 248.26 & 21.00 & 0.08 \\
\hline & \multirow{3}{*}{ 1,2-alternate } & $\alpha$ & 182.73 & 4.34 & 0.02 \\
\hline & & $\beta$ & 13.14 & 21.24 & 1.62 \\
\hline & & $\delta$ & 503.36 & 36.25 & 0.07 \\
\hline & \multirow{3}{*}{ 1,3-alternate } & $\alpha$ & 182.71 & 6.11 & 0.03 \\
\hline & & $\beta$ & 408.02 & 44.79 & 0.11 \\
\hline & & $\delta$ & 9.10 & 9.28 & 1.02 \\
\hline \multirow{12}{*}{ Heteroatom } & \multirow{3}{*}{ cone } & $\alpha$ & 59.35 & 6.69 & 0.11 \\
\hline & & $\beta$ & 56.58 & 44.91 & 0.79 \\
\hline & & $\delta$ & 14.03 & 13.27 & 0.95 \\
\hline & \multirow{3}{*}{ partial cone } & $\alpha$ & 115.83 & 8.18 & 0.07 \\
\hline & & $\beta$ & 158.81 & 47.48 & 0.30 \\
\hline & & $\delta$ & 238.46 & 17.08 & 0.07 \\
\hline & \multirow{3}{*}{ 1,2-alternate } & $\alpha$ & 180.23 & 0.61 & 0.00 \\
\hline & & $\beta$ & 4.84 & 11.48 & 2.37 \\
\hline & & $\delta$ & 460.75 & 31.35 & 0.07 \\
\hline & \multirow{3}{*}{ 1,3-alternate } & $\alpha$ & 186.74 & 12.12 & 0.06 \\
\hline & & $\beta$ & 419.76 & 46.90 & 0.11 \\
\hline & & $\delta$ & 7.91 & 8.86 & 1.12 \\
\hline
\end{tabular}

From Table 4, it is obvious that the $\alpha$ parameter in all structures is relatively uniform because of the low value of its standard deviation. It can be demonstrated on the group of cone structures with average value of the $\alpha$ parameter of about $59^{\circ}$ in calix[4] arenes with methylene- or heteroatom-bridged groups and its standard deviation of about $6.5^{\circ}$; the value of the standard deviation of $\alpha$ is slightly higher in calix[4]arenes with heteroatom bridge groups because of their greater conformational flexibility caused by a larger cavity (the $\mathrm{C}-\mathrm{S}-\mathrm{C}$ bridge in the majority of these structures is significantly longer than the $\mathrm{C}-\mathrm{CH}_{2}-\mathrm{C}$ bridge in methylene-bridged structures). The $\beta$ parameter is significantly more flexible according to higher values of its standard deviation; the $\boldsymbol{\delta}$ parameter is similarly flexible as can be demonstrated on partial cone and 1,2-alternate structures of the calix[4]arenes with methylene or heteroatom bridge groups (see Table 4). The high standard deviation of the $\beta$ parameter in the group of cone methylene- and heteroatom-bridged calix[4]arenes is caused by possible deformation of the base frame towards $C_{2 v}$ symmetry; a relatively large number of both cone and flattened cone structures answers for the wider range of parameter $\beta$.

Our next work will be dedicated to evaluation of inter- and intramolecular effects which affect the geometry (and therefore the geometrical parameters $\boldsymbol{\alpha}, \boldsymbol{\beta}, \boldsymbol{\delta}$ ) in the previously discussed cone group. This group will be futher divided according to the type of the bridge into cone calix[4]arenes with methylene and heteroatom bridge groups. The partial cone, 1,2-alternate and 1,3-alternate groups will be discussed in a separate article (Part II).

\section{Methylene-bridged cone calix[4]arenes}

The group of cone conformers of calix[4]arenes with methylene bridge groups is the largest one (1182 complete cif files with 1442 independent molecules, 87 incomplete cif files, see Table 1). This group contains about $48 \%$ of symmetrically tetrasubstituted structures. The substitution patterns and the corresponding percentages of the cone group are given in Table 5 (10 duplicite hits are excluded from the total number). Metal-coordinated structures form $44 \%$ of these entries. 
The substitution patterns and the corresponding percentages of the cone group

\begin{tabular}{|c|c|c|c|c|}
\hline Type of substitution & \begin{tabular}{|c|}
$\begin{array}{c}\text { No. of cif } \\
\text { files }\end{array}$ \\
\end{tabular} & $\%$ & $\begin{array}{l}\text { No. of independ- } \\
\text { ent molecules }\end{array}$ & $\%$ \\
\hline Symmetrically tetrasubstituted & 607 & 47.83 & 701 & 48.61 \\
\hline Distally substituted lower rim, symmetrically tetrasubstituted upper rim & 303 & 23.88 & 332 & 23.02 \\
\hline Distally substituted upper rim, symmetrically tetrasubstituted lower rim & 106 & 8.35 & 126 & 8.74 \\
\hline Distally substituted upper rim and lower rim & 61 & 4.81 & 68 & 4.72 \\
\hline Proximally substituted lower rim, symmetrically tetrasubstituted upper rim & 33 & 2.60 & 33 & 2.29 \\
\hline Mono/trisubstituted lower rim, symmetrically tetrasubstituted upper rim & 81 & 6.38 & 90 & 6.24 \\
\hline Mono/trisubstituted upper rim, symmetrically tetrasubstituted lower rim & 14 & 1.10 & 17 & 1.18 \\
\hline Other & 74 & 5.83 & 75 & 5.20 \\
\hline Total & 1269 & 100 & 1442 & 100 \\
\hline
\end{tabular}

Since there are over 1200 hits in this group and nearly a half of these hits are complexes, uncomplexed and metal-coordinated structures are discussed separately.

\section{Uncomplexed methylene-bridged cone calix[4]arenes}

The $\alpha-\beta$ plot for the uncomplexed structures is depicted in Figure 8. The legend to this figure is: - symmetrically tetrasubstituted structure; - distally substituted lower rim, symmetrically tetrasubstituted upper rim; $\boldsymbol{\Delta}$ distally substituted upper rim, symmetrically tetrasubstituted lower rim; $\boldsymbol{\nabla}$ distally substituted both rims; $\square$ proximally substituted lower rim, symmetrically tetrasubstituted upper rim; $\Delta$ mono/trisubstituted lower rim, symmetrically tetrasubstituted upper rim; $\circ$ other substitution patterns. The $\alpha-\delta$ plot is depicted in the Supplementary Materials (Fig. S-4). Since the $\beta-\delta$ plot contains little information beyond the $\alpha-\beta$ and $\alpha-\delta$ plots, this figure is not reported.

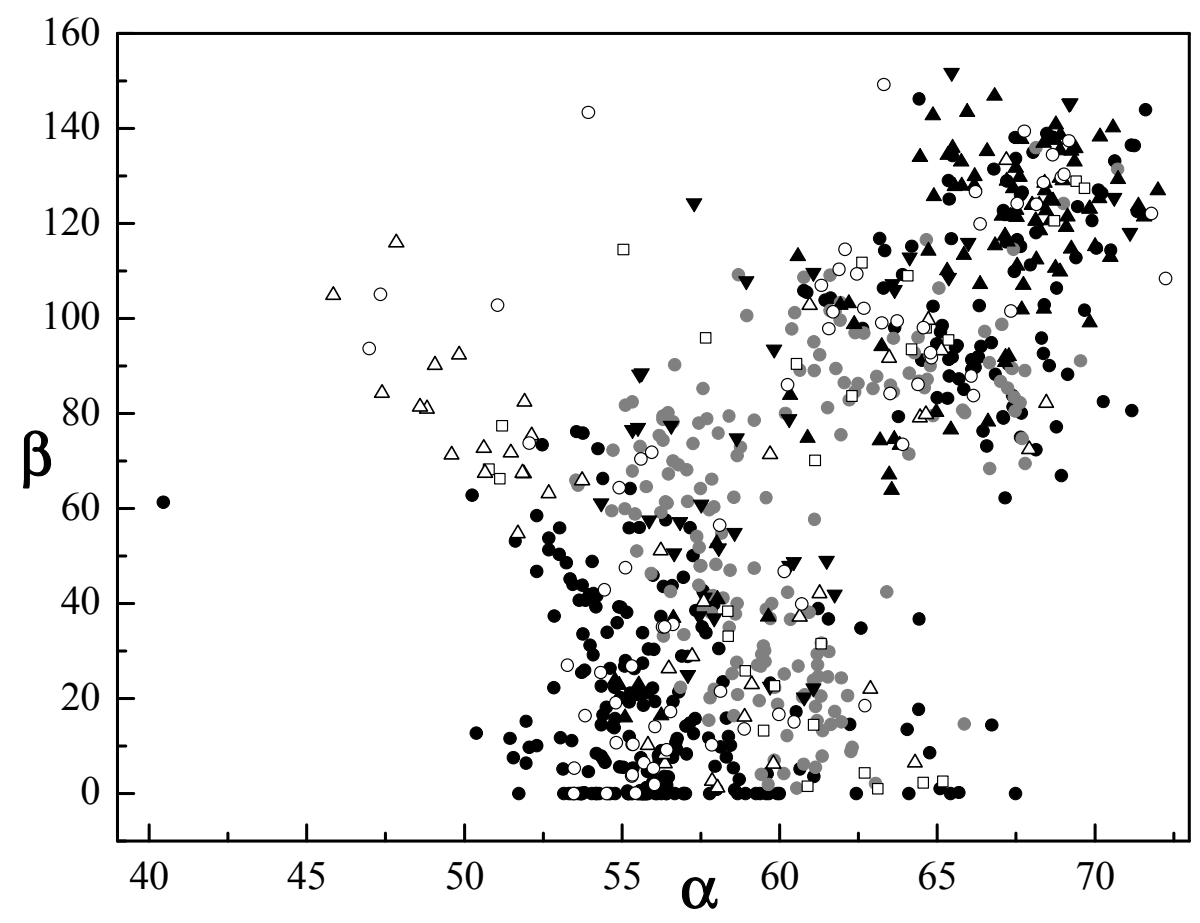

Figure 8 . The $\alpha-\beta$ plot for the group of uncomplexed cone calix[4]arenes

From Figure 8 ( $\alpha-\beta$ plot), it can be seen that the symmetrically tetrasubstituted uncomplexed structures form two groups: one with lower $\alpha$ and $\beta$ and the other with higher $\alpha$ and $\beta$. The same is true for all distally and lower rim proximally substituted structures. Lower rim mono/trisubstituted structures form similar two groups, the one at lower $\alpha$ reaches beyond the 'main' group towards higher $\beta$. 
Since the vast majority of structures in Figure S-4 have low $\delta$ and the value of the $\delta$ parameter seems to depend mostly on weak inter- and/or intramolecular interactions, this parameter is not discussed in the following chapters unless a clear correlation is found.

\section{Symmetrically tetrasubstituted uncomplexed methylene-bridged cone structures}

These molecules form two distinct groups in Fig. 8: one at 50 $<\alpha<60^{\circ}$ and $\beta<80^{\circ}$ ('cluster' 9-I; 160 cif files with 203 independent molecules), the second one at $\alpha>60^{\circ}$ and $\beta>60^{\circ}$ ('cluster' 9-II; 81 cif files with 94 independent molecules). The distribution of structures into these two groups depends primarily on lower rim substitution (see Fig. 9).

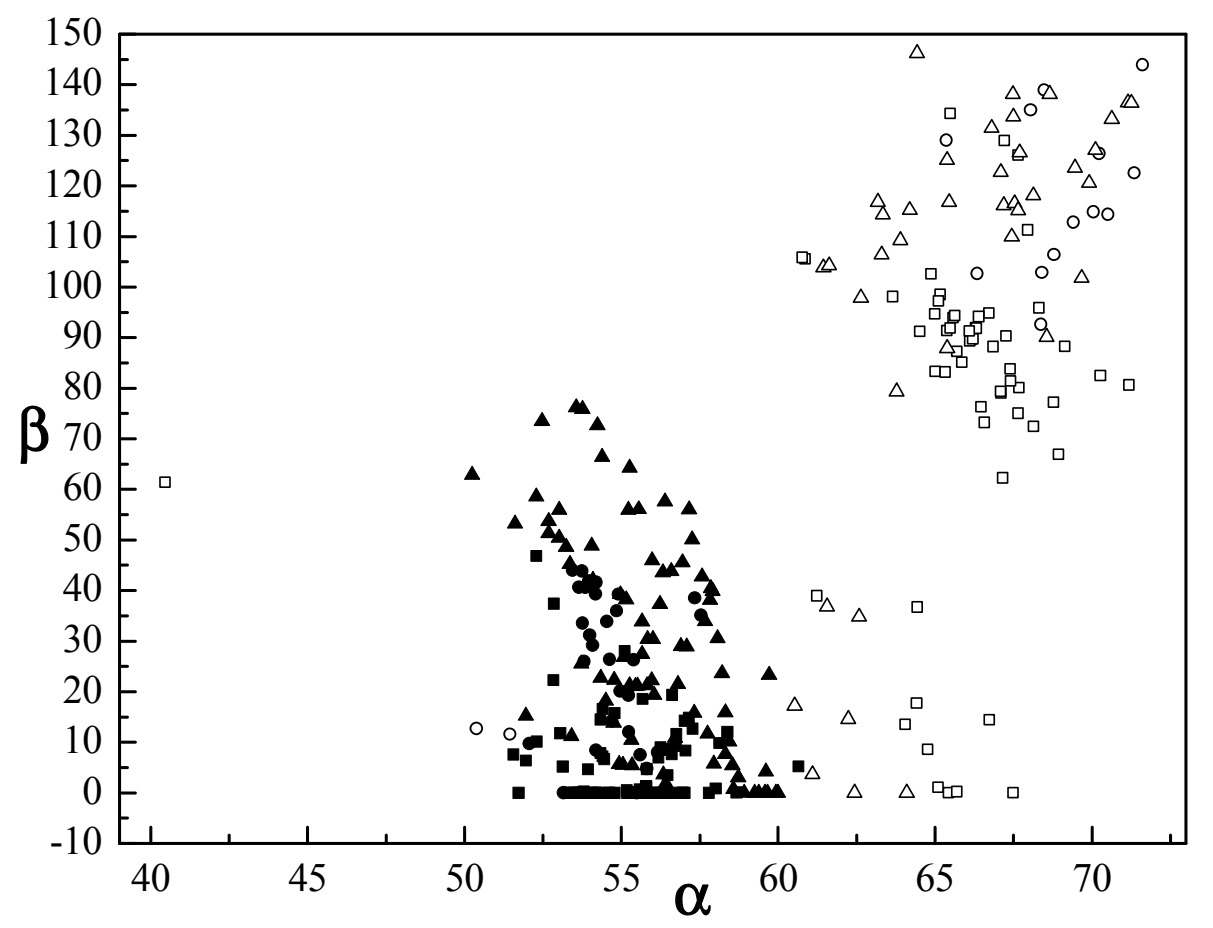

Structures containing four hydroxyl groups at the lower rim have solid symbols, structures with alkylated/acylated lower rim phenolic oxygen atoms have hollow symbols,

- $\square$ structure substituted by nonpolar alkyl/aryl groups at the upper rim;

- o upper rim unsubstituted structure;

$\Delta \Delta$ structure substituted by polar groups at the upper rim

Figure 9. Effect of substitution on the symmetry of the calix[4]arene scaffold in symmetrically tetrasubstituted uncomplexed structures

The first 'cluster' at lower $\alpha$ and $\beta$ ('cluster' 9-I; center at $[\alpha ; \beta ; \delta]$ of $[55.43 ; 18.42 ; 6.01]$, standard deviation of $[1.90 ; 19.79 ; 7.12])$ is formed principally by structures with unsubstituted lower rim hydroxyl groups. These molecules contain a cyclic array of hydrogen bonds at the lower rim; this arrangement has the lowest energy when the molecule is symmetrical (e.g. $\mathrm{C}_{4 \mathrm{v}}$ symmetry) and therefore the most symmetrical arrangement of the calix[4]arene scaffold is preferred in these structures. Deformations of this base frame are usually small $\left(\beta<60^{\circ}\right.$ for the vast majority of structures) because disruption of the lower rim hydrogen bonds is energetically unfavorable. Moreover, because of the array of hydrogen bonds and lack of sterical hindrance at the lower rim (no bulky lower rim substituents), more open structures are possible; these molecules therefore tend to have lower $\alpha\left(<60^{\circ}\right)$ than structures substituted at the lower rim phenolic oxygen atoms $\left(>60^{\circ}\right)$; see Figure 9.

There are also a few structures with substituted lower rim phenolic oxygen atoms close to 'cluster' 9-I; because of the lower rim substitution and therefore the resulting sterical hindrance at the lower rim, the $\alpha$ parameter is $>60^{\circ}$ in these structures. These structures are mostly clathrates which accounts for their low $\beta$. Among the structures from 'cluster' 9-I, there are clathrates of 5,11,17,12-tetrakis( $t$-butyl)-25,26,27,28tetrahydroxycalix[4]arene (52 complete cif files) and of similar calixarenes containing nonpolar upper rim 
substituents (17 complete cif files). Clathrates with small, symmetrical aliphatic molecules tend to have the most symmetrical $\mathrm{C}_{4 \mathrm{v}}$ geometry (see Fig. I-1, structure ZAHMOK [7]). Clathrates containing flat aromatic molecules inside the cavity tend to be slightly deformed in $\beta$ (usually $<20^{\circ}$ ) because of the presence of intermolecular $\pi, \pi$-interactions. However, even clathrates containing large nonsymmetrical and aromatic molecules inside the calixarene cavity have the $\mathrm{C}_{4 \mathrm{v}}$ geometry in case the solvent is disordered. Because of the symmetrical calixarene conformation the disorder in this case is probably dynamic. Specific class of clathrates are those containing aliphatic amines; these structures tend to have larger $\beta\left(<40^{\circ}\right)$ and $\delta\left(<30^{\circ}\right)$ because of deprotonation of lower rim hydroxyl groups by the basic amine and the resulting effect on the cyclic array of hydrogen bonds at the lower rim (destabilization of the symmetrical $\mathrm{C}_{4 \mathrm{v}}$ geometry). Structures where the calixarene has no solvent inside the cavity are also slightly deformed $\left(\boldsymbol{\beta}, \boldsymbol{\delta}<20^{\circ}\right)$; however, the cyclic array of hydrogen bonds present at the lower rim keeps the calixarene geometry close to $C_{4 v}$.

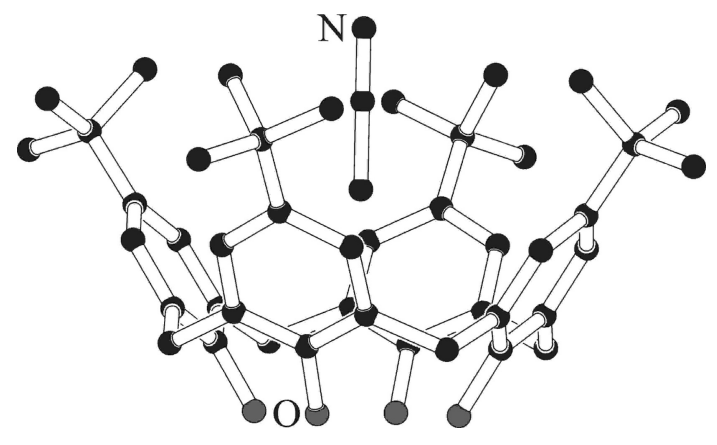

Figure I-1. Structure ZAHMOK [7]

Next group of the lower rim hydroxyl-substituted structures are clathrates of 25,26,27,28tetrahydroxycalix[4]arene (24 complete cif files). The rules in the previous paragraph apply also to these clathrates; however, because of the missing $t$-butyl group and therefore no sterical hindrance at the upper rim the above-mentioned effects are more pronounced and these structures tend to be more deformed towards $\mathrm{C}_{2 \mathrm{v}}$ geometry $\left(\beta<50^{\circ}\right)$.

Polar substituents at the upper rim bring the possibility of intramolecular interaction between these substituents on opposite calixarene phenyl rings and therefore further deformation towards $\mathrm{C}_{2 \mathrm{v}}$ symmetry. The largest group among these structures is formed by structures of 5,11,17,12-tetrasulfonato-25,26,27,28tetrahydroxycalix[4]arene (39 complete cif files). These structures are clathrates with a wide range of geometries; the bigger and less symmetrical molecule in the cavity, the more $\mathrm{C}_{2 \mathrm{v}}$-deformed is the structure (Fig. I-2). The $\beta$ parameter is usually lower than $60^{\circ}$, three structures have this parameter above $70^{\circ}$.

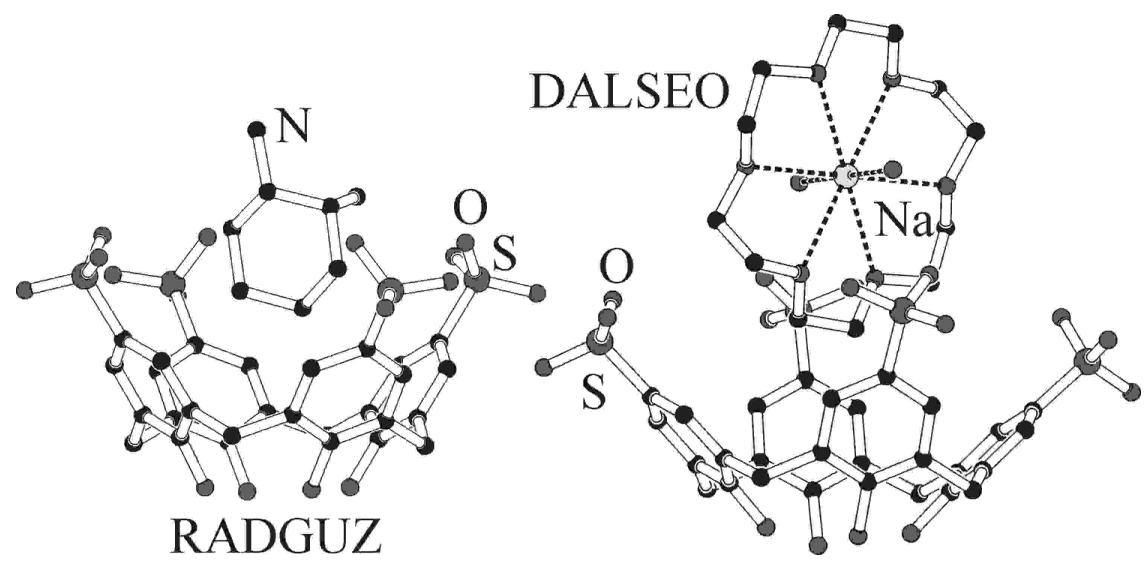

Figure I-2. Structures RADGUZ, DALSEO [7]

Structures alkylated or acylated at the lower rim hydroxyl groups do not possess the energetically favorable arrangement of cyclic hydrogen bonds at the lower rim and can therefore have higher $\boldsymbol{\beta}$ values. The majority of these structures forms the group at higher $\alpha, \beta$ in Fig. 9 ('cluster' 9-II; centered at [66.86; 103.29; $8.00]$ with a standard deviation of $[2.36 ; 20.31 ; 7.74])$. 
All structures from 'cluster' 9-II have substituted lower rim phenolic oxygen atoms and therefore $\alpha>$ $60^{\circ}$ because of sterical hindrance of four lower rim substituents. $\beta$ ranges from $60^{\circ}$ to $150^{\circ}$ and the calixarene base frame is therefore significantly deformed towards $\mathrm{C}_{2 \mathrm{v}}$ geometry. These structures contain no solvent in the cavity and thus display unhindered $\pi, \pi$-interaction between one pair of calixarene opposite phenyl rings. This effect is best observable in structures which do not contain any substituent at the upper rim and especially in structures which contain polar upper rim substituents which are subject to $\pi$, $\pi$ - or other interaction $\left(\mathrm{NO}_{2}, \mathrm{CN}, \mathrm{C} \equiv \mathrm{CH}\right.$ etc.). Such structures have $\beta>100^{\circ}$. On the other hand, nonpolar and branched upper rim substituents ( $t$-butyl) do not allow these phenyl rings so close because of sterical reasons and such structures have $60^{\circ}<\boldsymbol{\beta}<100^{\circ}$. An example of the above-mentioned effects is given in Fig. I-3.

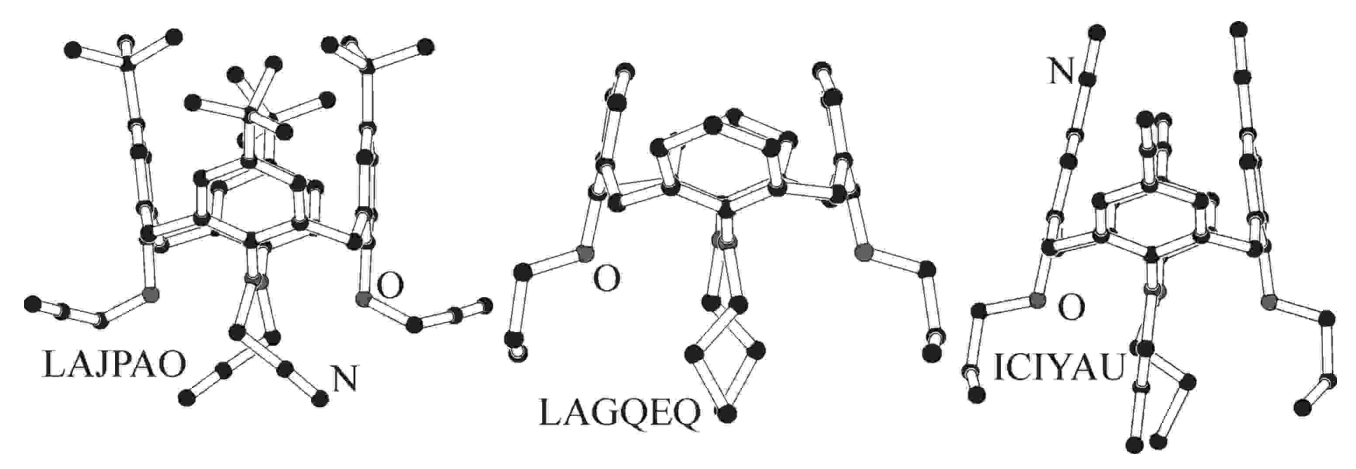

Figure I-3. Structures LAJPAO ( $\boldsymbol{\beta} \sim 80^{\circ}$, t-butyl groups at the upper rim), LAGQEQ $\left(\boldsymbol{\beta} \sim 110^{\circ}\right.$, unsubstituted upper rim) and ICIYAU ( $\beta \sim 120^{\circ}, \mathrm{NC}$ groups at the upper rim) [7]

There is one structure with $\alpha \sim 40^{\circ}$ which has not been included in 'clusters' 9-I and 9-II (structure HEMHUC [7] with a four-fold bridge at the lower rim, see Fig. I-4). The rigid arrangement of bonds at the phosphorus heteroatom forces the structure more open and the $\alpha$ parameter is therefore very low.

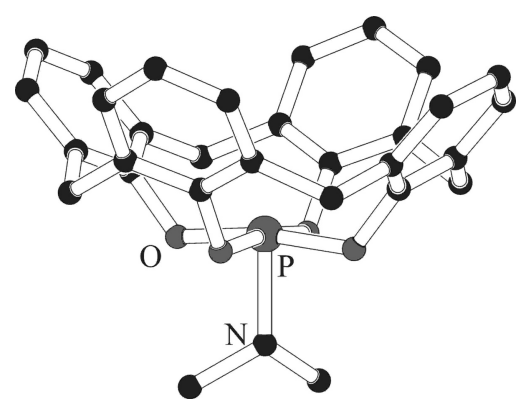

Figure I-4. Structure HEMHUC [7]

From the group of clathrates which contain substituted lower rim phenolic oxygen atoms (the small group of structures at $\alpha>60^{\circ}$ and $\beta<40^{\circ}$ ) it is obvious that solvent molecule inside the calix[4]arene cavity, which prevents the opposite calix[4] arene phenyl rings from coming to a close proximity, can have a significant impact on the calix[4]arene geometry. This effect of a filled/empty cavity can be demonstrated in Fig. 10 ( $\alpha-\beta$ plot). The majority of structures with empty cavity and $\beta<60^{\circ}$ have also unsubstituted lower rim hydroxyl groups (compare to Fig. 9); it therefore seems that the effect of the cyclic array of hydrogen bonds at the lower rim overrides the effect of a filled/empty cavity in calix[4]arene structures. This finding is in accordance with the relative strength of hydrogen bonds and van der Waals interactions.

Several types of clathrates in cone calix[4]arene structures are possible: the cavity may be filled by a small molecule (usually solvent), by a lower rim substituent from another calixarene molecule, by a upper rim substituent from another calixarene molecule or even from the parent calixarene molecule, or, in the case of upper rim unsubstituted calixarenes, the upper rim from one calixarene may reach into the cavity of the other calixarene. These types are distinguished in Figure 10. 


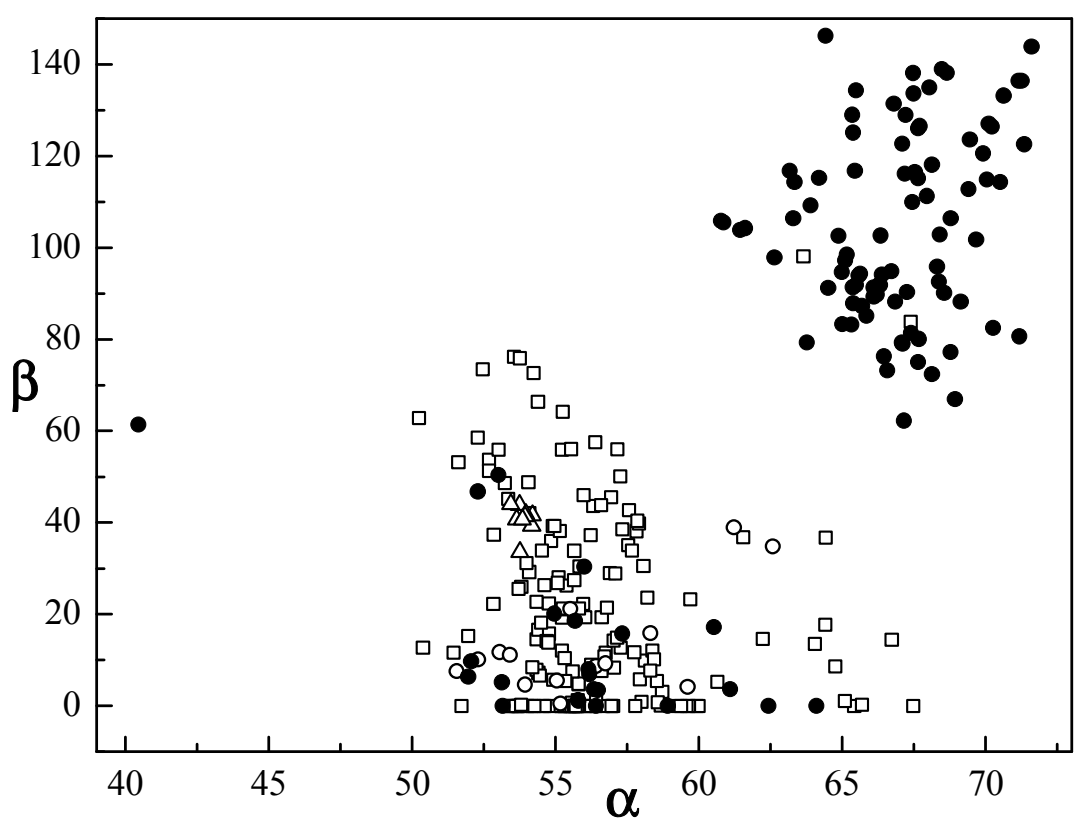

$\square$ - solvent molecule inside the calixarene cavity; ○ — upper rim substituent inside the calixarene cavity; $\Delta$ - unsubstituted upper rim from another calixarene molecule inside the cavity; $\bullet$ - empty calix [4]arene cavity

Figure 10. Effect of a filled/empty cavity on the symmetry of the calix[4]arene scaffold in symmetrically tetrasubstituted uncomplexed cone structures

\section{Lower rim distally substituted, upper rim symmetrically tetrasubstituted uncomplexed methylene-bridged cone calix[4]arenes}

The group of lower rim distally substituted, upper rim symmetrically tetrasubstituted uncomplexed cone calix[4]arenes contains 169 cif files and tends to be somewhat more deformed in parameter $\beta$ than the symmetrically tetrasubstituted group, one reason probably being less symmetrical substitution at the lower rim.

There are two distinct groups in Fig. 8: 'cluster' 8-I at high $\alpha\left(>60^{\circ}\right)$ and $\beta\left(>70^{\circ}\right)$ and the second, somewhat diffuse 'cluster' 8-II at $\alpha<62^{\circ}$ and $\beta<80^{\circ}$. 'Cluster' 8-I contains 56 cif files with 61 independent molecules, is centered at $[64.12 ; 93.17 ; 10.30]$ with a standard deviation of $[2.77 ; 12.76 ; 8.48]$. 'Cluster' 8-II contains 105 cif files with 120 independent molecules, is centered at $[58.57 ; 42.45 ; 7.41]$ with a standard deviation of $[2.07 ; 23.76 ; 5.54]$. Since the lower rim hydroxyl groups of these structures are at least partially substituted and the cyclic array of lower rim hydrogen bonds is therefore disrupted, profound deformation towards $\mathrm{C}_{2 \mathrm{v}}$ symmetry (as in 'cluster' 8-I) is possible in these molecules. As a rule of thumb, structures with all lower rim phenolic oxygen atoms alkylated or acylated tend to be in 'cluster' 8-I; structures retaining two lower rim hydroxyl groups and therefore some hydrogen bonds at the lower rim are usually more symmetrical (Fig. 11). Clathrates tend to be in 'cluster' 8-II thanks to their lower $\beta$ (effect of a filled cavity, see Fig. 12) whereas structures with empty cavity where intramolecular $\pi$, $\pi$-interaction between two opposite calixarene phenyl rings is not disrupted are deformed towards $\mathrm{C}_{2 \mathrm{v}}$ geometry and fall into 'cluster' 8-I.

There are 13 structures in this group which contain two calix[4]arene molecules connected by covalent bonds; one structure with distal upper rim - lower rim bridge and 12 structures with distal lower rim lower rim bridge. The geometry of the calixarene base frame in these structures is mostly governed by the effect of filled/empty cavity (see above).

There are also 41 structures which contain one lower rim distal bridge (two lower rim distal bridges were not observed because of sterical reasons). The geometry of the calixarene base frame in these structures is again mostly dependent on the effect of filled/empty cavity. The vast majority of these structures contain long and flexible crown ether bridges at the lower rim and the geometry of the calix[4]arene molecules is therefore little affected by the presence of lower rim bridge.

The rest of this chapter will deal exclusively with nonbridged structures. First, the effect of the upper rim substituent will be discussed. There are 80 structures which contain $t$-butyl groups at the upper rim, 33 structures with unsubstituted upper rim and only two structures which contain other substituents at the upper rim. 


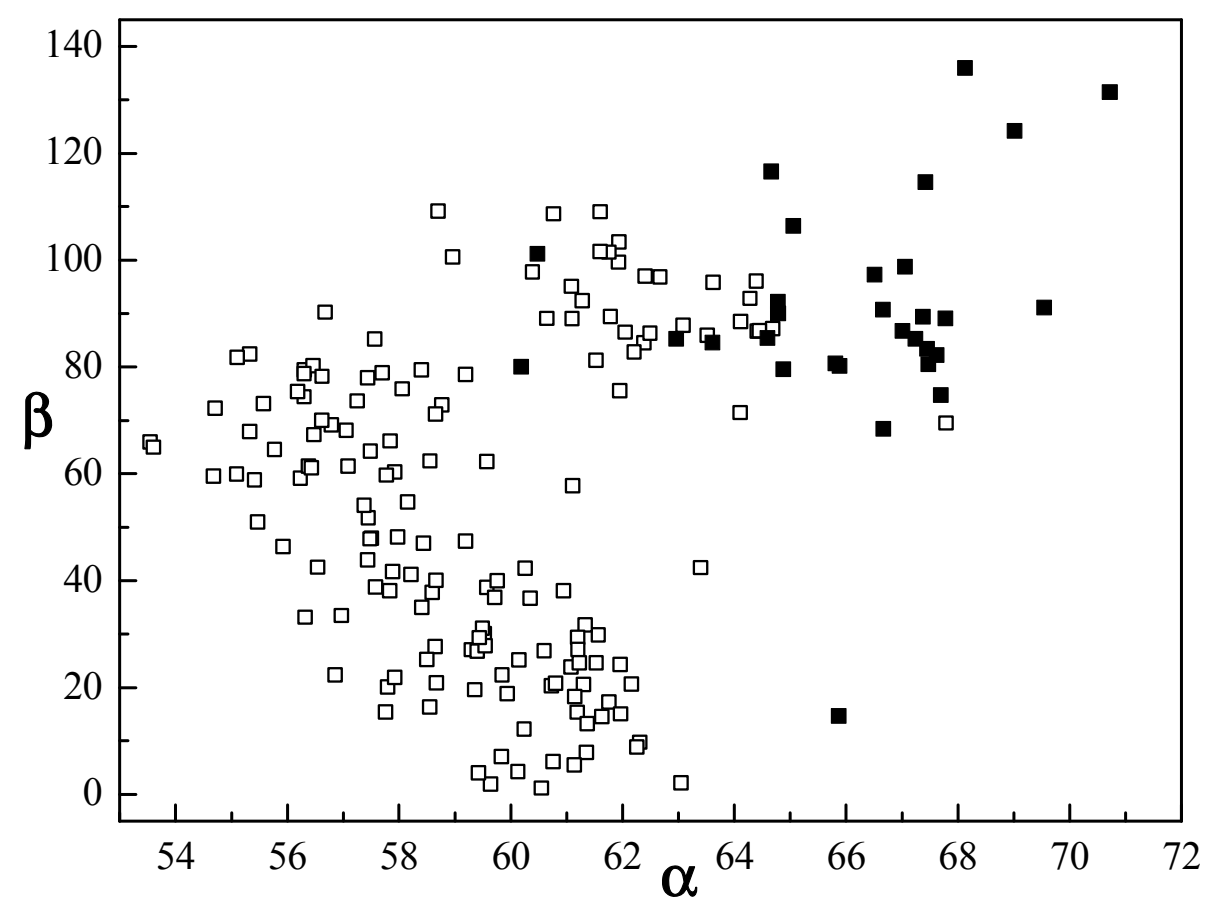

$\square-$ structures with two remaining hydroxyl groups at the lower rim;

- - structures with all lower rim phenolic oxygen atoms alkylated or acylated

Figure 11 . The effect of lower rim substitution on the symmetry of the calix[4]arene scaffold)

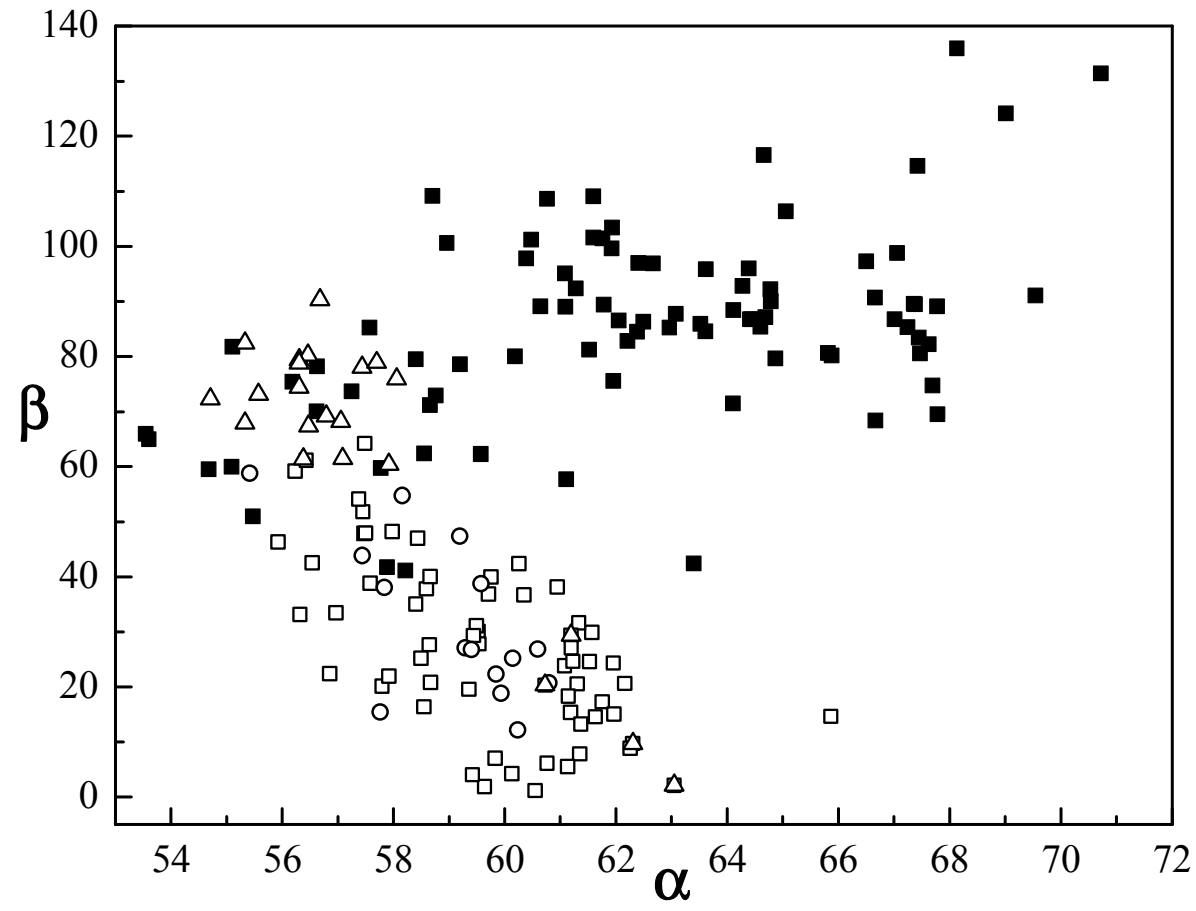

$\square$ — small solvent molecule inside the cavity; ○ — lower rim substituent from another calixarene molecule inside the cavity; $\Delta$ - unsubstituted upper rim from another calixarene molecule inside the cavity; - empty calixarene cavity

Figure 12. The effect of a filled/empty cavity on the symmetry of the calix[4]arene

The structures with unsubstituted upper rim have somewhat bigger flexibility due to lack of sterical hindrance at the upper rim. All these structures have $\alpha<60^{\circ}$ and $\beta<90^{\circ}$ and belong therefore to 'cluster' 8 -II 
in Figure 8. The parameter $\beta$ seems to depend on the type of clathrate the structure belongs to (see Fig. S-5 in the Supplementary Materials), no dependence on the lower rim substituent was observed.

Similar dependence can be plotted for the group of upper rim $t$-butyl-substituted structures (Fig. 13). It can be seen that the group of calixarenes with empty cavity forms the majority of 'cluster' 8-I in Figure 8 (high $\alpha$ and $\beta$ ). Structures which have all lower rim hydroxyl groups alkylated or acylated belong entirely into this group along with some structures which are substituted on two distal hydroxyl groups only. On the other hand, clathrates belong entirely to 'cluster' 8-II with lower $\alpha$ and $\beta$ in Fig. 8; clathrates which contain large and/or aromatic molecules inside the cavity tend to be more deformed towards $\mathrm{C}_{2 \mathrm{v}}$ symmetry than clathrates with small aliphatic molecules.

Since these structures contain bulky $t$-butyl groups at the upper rim, clathrates in which one upper rim of calixarene molecule reaches into the cavity of another calixarene molecule were not observed.

As in the group of upper rim unsubstituted calix[4]arenes, no distinct dependence of parameters $\boldsymbol{\alpha}, \boldsymbol{\beta}$ on the type and size of the lower rim substituents was observed for the group of upper rim $t$-butyl substituted structures.

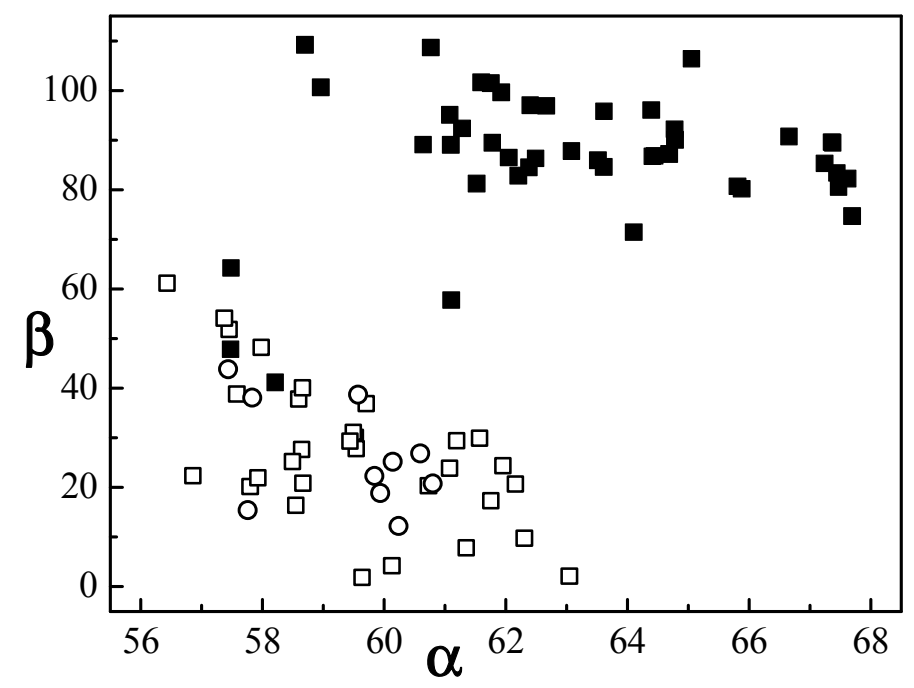

- - no molecule inside the cavity; $\square$ — small solvent molecule inside the cavity;

$\circ$ - lower rim substituent from another calixarene molecule inside the cavity

Figure 13. The dependence of the parameter $\boldsymbol{\beta}$ on the type of clathrate in upper rim $t$-butyl substituted structures

In the group of lower rim distally substituted, upper rim symmetrically tetrasubstituted uncomplexed calix[4]arenes, the vast majority of structures has $\delta<25^{\circ}$ and is therefore little deformed towards $\mathrm{C}_{\mathrm{s}}$ symmetry. However, there are five structures with $\boldsymbol{\delta}>30^{\circ}$; the $\mathrm{C}_{\mathrm{s}}$-deformation in these structures is caused by nonsymmetrical inter- and/or intramolecular $\mathrm{CH}-\pi$ and $\pi, \pi$-interactions (Fig. I-5).

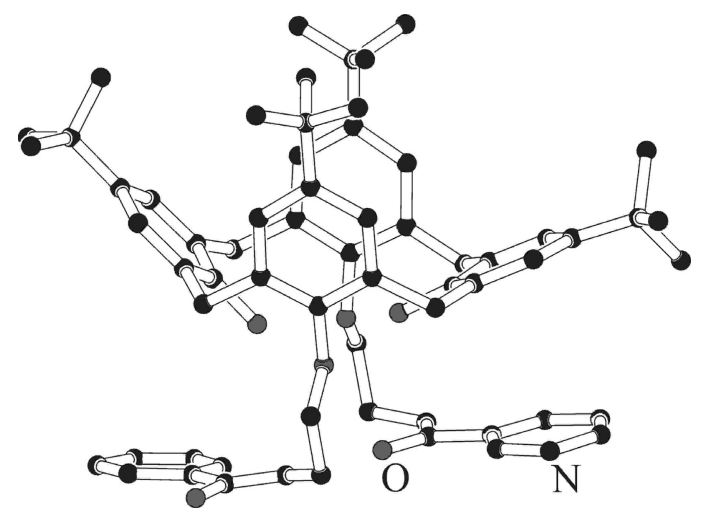

Figure I-5. $\mathrm{C}_{\mathrm{s}}$-deformed structure AZOMIL [7] 


\section{Upper rim distally substituted, lower rim symmetrically tetrasubstituted uncomplexed methylene-bridged cone calix[4]arenes}

This group contains 89 cif files with 104 independent molecules. From Figure 8, it can be clearly seen that the vast majority of upper rim distally substituted, lower rim symmetrically tetrasubstituted uncomplexed cone calix[4]arenes tends to cluster at high $\alpha\left(>60^{\circ}\right)$ and $\beta\left(>80^{\circ}\right)$. This result is no surprise because the vast majority of structures in this group has substituted all lower rim phenolic oxygen atoms. However, there are several structures with lower $\alpha$ and $\beta$ and therefore less $\mathrm{C}_{2 \mathrm{v}}$-deformed calixarene scaffold; these structures are clathrates and those with unsubstituted lower rim hydroxyl groups. Because of less symmetrical substitution and because the majority of the structures from this group contain polar substituents at the upper rim these effects are slightly blurred. Furthermore, all structures from this group have $\delta<30^{\circ}$ (Fig. S-4) and are therefore little deformed towards $\mathrm{C}_{\mathrm{s}}$ symmetry.

The above-mentioned effects of substitution and filled/empty cavity are summarized in Figures 14, 15. It is obvious that structures retaining lower rim hydroxyl groups and clathrates tend to have lower $\beta$, as observed for previously discussed groups.

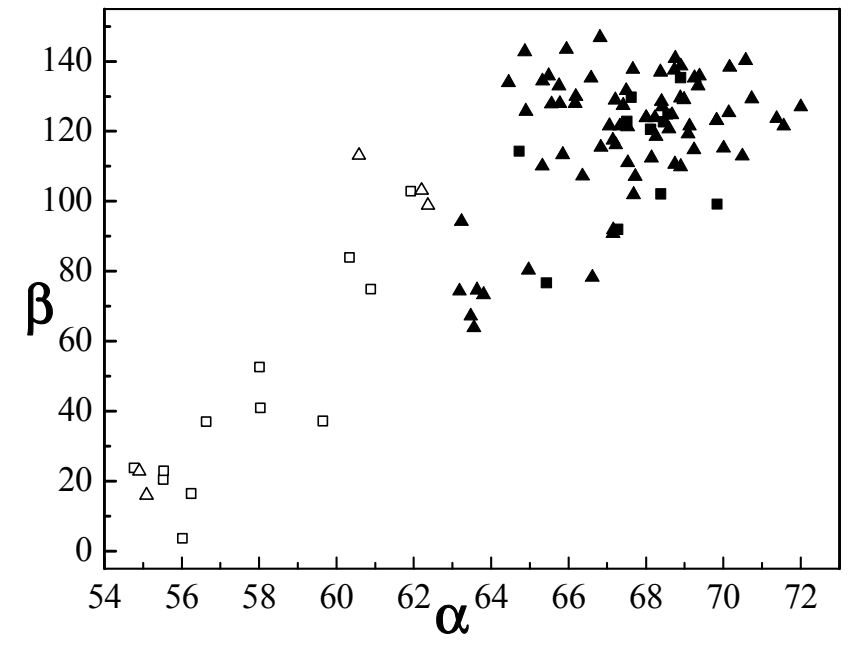

$\square-$ nonpolar groups at the upper rim, lower rim hydroxyl groups; - - nonpolar groups at the upper rim, substituted lower rim phenolic oxygen atoms; $\Delta$ - polar groups at the upper rim, lower rim hydroxyl groups;

$\boldsymbol{\Delta}$ - polar groups at the upper rim, substituted lower rim phenolic oxygen atoms

Figure 14. Effect of substitution on the geometry of the upper rim distally disubstituted,

lower rim symmetrically tetrasubstituted calix[4]arenes
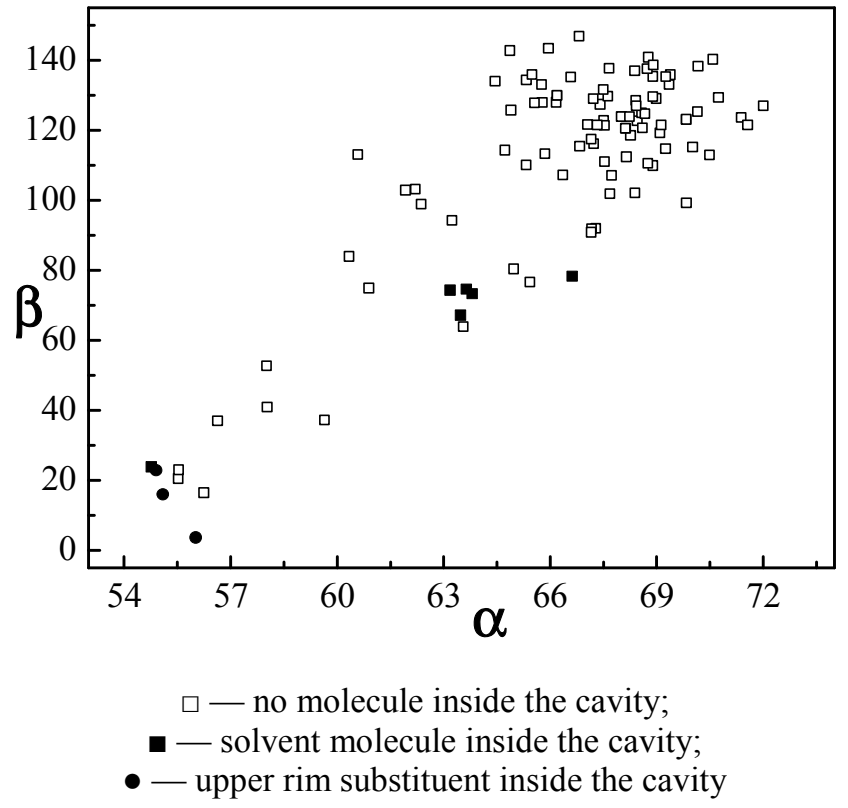

Figure 15. Effect of a filled/empty cavity on the geometry of the upper rim distally disubstituted, lower rim symmetrically tetrasubstituted calix[4]arenes

There are 11 structures in this group where two or more calixarene units are connected by covalent bonds: one lower rim - upper rim connected structure and 10 upper rim - upper rim connected structures. There are also 17 structures which contain a distal upper rim bridge. Linear dependence of the symmetry of the calix [4] arene scaffold on the length and rigidity of this bridge in structures containing aliphatic bridges is depicted in Figure 16. Short upper rim bridges force the calix[4]arene opposite phenyl rings closer and the structure is therefore significantly deformed towards $C_{2 v}$ geometry (large $\beta$ ).

The rest of this chapter deals with nonbridged structures. There are altogether eight clathrates in this group (structures in Figure 8 with $\alpha<65^{\circ}, \beta<80^{\circ}$ ). The rest of the structures contain no molecule in the calixarene cavity and are strongly deformed towards $C_{2 v}$ geometry $\left(\beta>90^{\circ}\right)$. The majority of these structures possesses polar upper rim substituents and have $\beta>100^{\circ}$; however, in the case of nonpolar bulky substituents on the upper rim of the closer pair of the calixarene phenyl rings the resulting sterical hindrance prevents these rings from coming to such a close proximity and the parameter $\beta$ is usually between $90^{\circ}$ and $100^{\circ}$ in this type of structures. 


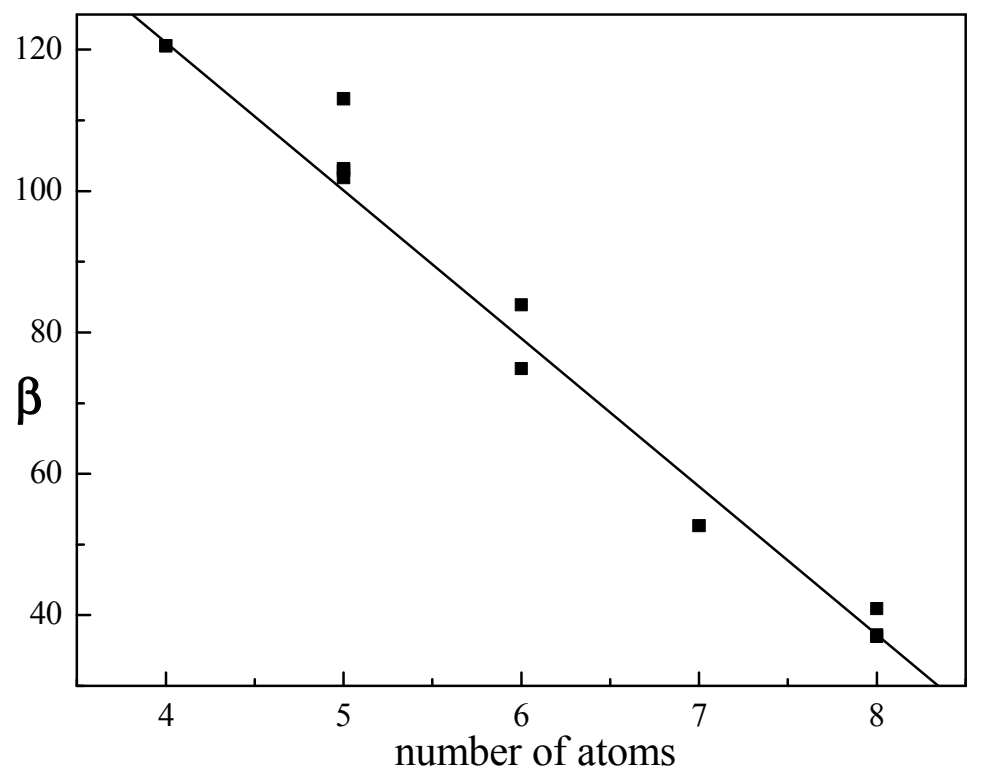

Figure 16. The dependence of parameter $\beta$ on the length (number of atoms) of the upper rim distal bridge (aliphatic bridges only)

The majority of structures with $\beta>90^{\circ}$ which are distally substituted on only one pair of upper $\operatorname{rim} p$ positions have these substituents on the more distant pair of the calixarene phenyl rings which minimizes sterical hindrance at the upper rim (intramolecular $\pi, \pi$-interaction is present between the pair of upper rim unsubstituted calixarene phenyl rings); however, in the case of substituents capable of some interaction $\left(\mathrm{NO}_{2}, \mathrm{COOH}, \mathrm{C}=\mathrm{C}\right.$ etc.) these substituents may be present on the closer pair of the calixarene phenyl rings and further enhance the intramolecular $\pi, \pi$-interaction (see Fig. I-6).

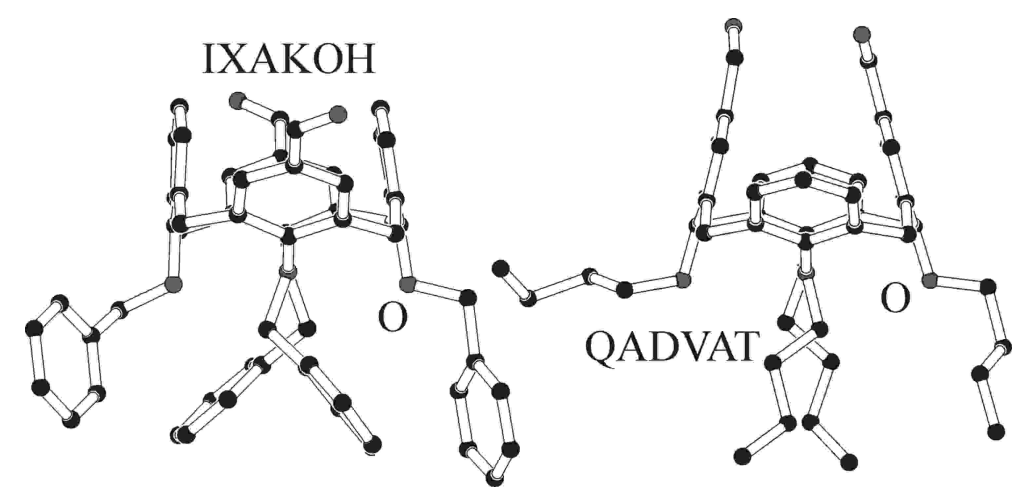

Figure I-6. Upper rim formyl-substituted structures IXAKOH $\left(\boldsymbol{\beta}=115^{\circ}\right)$ and QADVAT $\left(\boldsymbol{\beta}=138^{\circ}\right)[7]$

There are altogether 39 structures with empty cavity $\left(\beta>90^{\circ}\right)$ which contain 1-propoxy groups at the lower rim; however, no correlation between parameters $\alpha, \beta$ and the type and size of upper rim substituents was found.

\section{Uncomplexed methylene-bridged cone calix[4]arenes distally substituted at both rims}

This group contains 34 hits with 39 independent molecules. As in the group of lower rim distally substituted, upper rim symmetrically tetrasubstituted uncomplexed cone calix[4]arenes, this group of structures tends to be somewhat more deformed in parameter $\beta$ than the symmetrically tetrasubstituted group, probably because of less symmetrical substitution at the upper and lower rim. All structures from this group have $\boldsymbol{\delta}<20^{\circ}$ and are therefore little $\mathrm{C}_{\mathrm{s}}$-deformed.

From Figures 8 and S-4 it can be seen that this group is very diffuse (varying greatly in $\beta$ ) and does not form any distinct 'clusters' as observed in previous chapters. 
There is one structure which contains two calix[4]arene units with covalently connected lower rims, one structure with covalently connected upper rims and one structure with two calix[4]arene units distally appended by their lower rims to another calix[4]arene upper rim. There are also four distally bridged structures: one at upper rim, one at lower rim and two at both rims (on the same phenyl rings).

The dependence of parameter $\beta$ on the type of the clathrate in nonbridged structures is depicted in Fig. S-6 in the Supplementary Materials.

Since there are only a few structures in this group and these structures vary widely in substitution, no correlation between the size and type of upper/lower rim substituents and parameters $\alpha, \beta$ was found. However, structures with no solvent molecule inside the cavity and only one pair of upper rim $p$ - positions substituted tend to have these substituents on the more distant pairs of calixarene phenyl rings and thus minimize sterical hindrance at the upper rim (see previous chapter).

An interesting effect was observed among structures with no solvent molecule inside the cavity. Structures with all lower rim hydroxyl groups substituted have $\beta>105^{\circ}$ whereas structures with only one distal pair of hydroxyl groups substituted have $\beta<95^{\circ}$ and less deformed calixarene base frame. Similar effect has been observed in the lower rim distally substituted, upper rim symmetrically tetrasubstituted group. It seems that although the cyclic array of lower rim hydrogen bonds in these structures is broken, its remnants in structures which retain some hydroxyl groups at the lower rim contribute to stabilization of the less deformed conformation.

\section{Lower rim proximally substituted, upper rim symmetrically tetrasubstituted uncomplexed methylene-bridged cone calix[4]arenes}

This group contains 28 cif files with 28 independent molecules. From Figures 8 and S-4 it can be seen that these structures form two very diffuse groups: one with $\beta<40^{\circ}$ and the second one with $\beta>60^{\circ}$. The structures in these groups vary widely in parameter $\alpha$ (especially in the second one). Molecules from the first group are mostly clathrates with less deformed calixarene base frame whereas molecules from the second group have usually empty cavity.

There is also a very large number (78 \%) of lower rim proximally bridged structures (18 out of 23 complete cif files). Structures with short (one atom) proximal bridges tend to have $\alpha<60^{\circ}$ compared to structures with longer aliphatic bridges which have $\alpha>60^{\circ}$. The parameter $\beta$ depends on whether the structure is a clathrate or not (clathrates usually have lower $\beta$ ) and is therefore not informative.

There are also 6 structures ( $26 \%$ of complete cif files) with $\delta>20^{\circ}$; it seems that less symmetrical proximal lower rim substitution is reflected in parameter $\boldsymbol{\delta}$ as compared to the distal one. The structures with $\delta>20^{\circ}$ display intermolecular $\pi, \pi$ - or $\mathrm{CH}-\pi$ interaction between different calixarene molecules or intramolecular $\pi, \pi$-interaction between calixarene phenyl rings and lower rim aromatic substituents.

\section{Lower rim mono/trisubstituted, upper rim symmetrically tetrasubstituted uncomplexed methylene-bridged cone calix[4] arenes}

There are 39 cif files with 45 independent molecules in this group. In Figure 8, three distinct groups can be observed: 'cluster' 8-III at $\beta<50^{\circ}$ and $\alpha \sim 58^{\circ}$ (14 cif files with 16 independent molecules, centered at [58.68; 20.55; 15.76], standard deviation of [2.44; 15.33; 7.27]), 'cluster' 8 -IV at $\alpha<55^{\circ}$ and $\beta>50^{\circ}$ (14 cif files with 18 independent molecules, centered at $[50.31 ; 78.34 ; 32.47]$, standard deviation of $[2.02 ; 14.83$; 9.83]) and 'cluster' $8-\mathrm{V}$ at $\alpha>60^{\circ}$ and $\beta>70^{\circ}$ (11 cif files with 11 independent molecules, centered at $[64.56 ; 90.71 ; 15.96]$, standard deviation of $[2.57 ; 16.74 ; 9.81])$.

'Cluster' 8-III is almost entirely formed by lower rim nonbridged clathrates; two types of clathrates (small aliphatic or aromatic organic molecules, aliphatic and aromatic lower rim substituents inside the cavity) fall into this group. Clathrates with aromatic molecules inside the cavity tend to have somewhat larger $\beta\left(\sim 40^{\circ}\right)$ than those with aliphatic ones.

Structures which retain three hydroxyl groups at the lower rim tend to have more symmetrical conformation than those with three or all hydroxyl groups substituted because these structures retain most hydrogen bonds at the lower rim. Such structures usually belong to 'cluster' 8-III.

'Cluster' $8-\mathrm{V}$ is formed by lower rim nonbridged structures with empty cavity. Structures with substituted three or all hydroxyl groups at the lower rim usually belong to this group. Since the majority of these structures has bulky $t$-butyl substituents at the upper rim, the parameter $\boldsymbol{\beta}$ tends to be somewhat lower (between $70^{\circ}$ and $100^{\circ}$ ) because of sterical hindrance at the upper rim. 
Lower rim single atom 'triple-bridged' structures form 'cluster' 8-IV. There is one monomeric structure with lower rim single atom 'triple bridge' (ABIHIC01 [7]) and two structures with a longer lower rim 'triple bridge' (ABOYAR(01), QIFHOC [7]). Structure ABIHIC01 has a very open cavity $\left(\alpha \sim 52^{\circ}\right)$ because of the short bridge at the lower rim which forces it more open; however, structures with longer bridges which tend to be much more flexible do not fall into 'cluster' 8-IV and have $\alpha \sim 63^{\circ}$ (Fig. I-7).

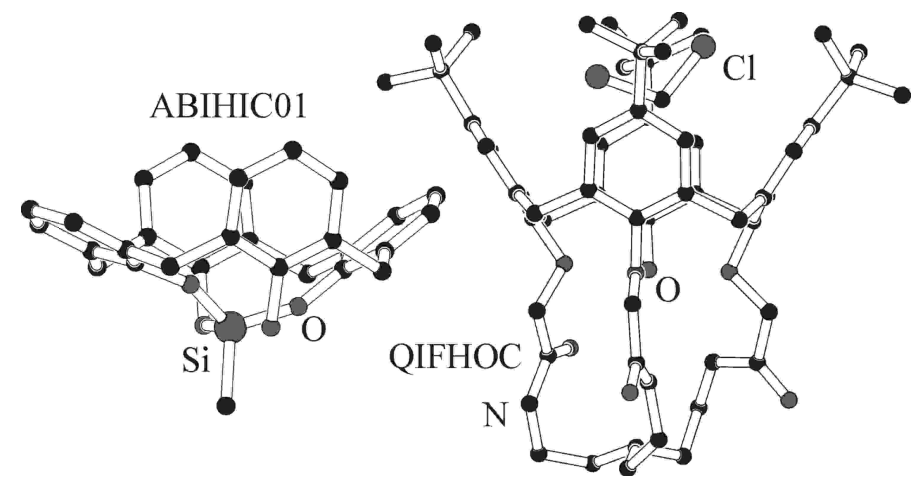

Figure I-7. Structures ABIHIC01, QIFHOC [7]

Other lower rim single atom 'triple-bridged' structures (13 cif files) belonging to 'cluster' 8-IV contain two calixarene units covalently linked by their lower rims as shown in Fig. I-8 (structure TAYJOS [7]); all these structures are clathrates (mostly with aromatic molecules). As shown in ABIHIC01, this type of bridge forces the structure more open and these structures have $\alpha<55^{\circ}$.

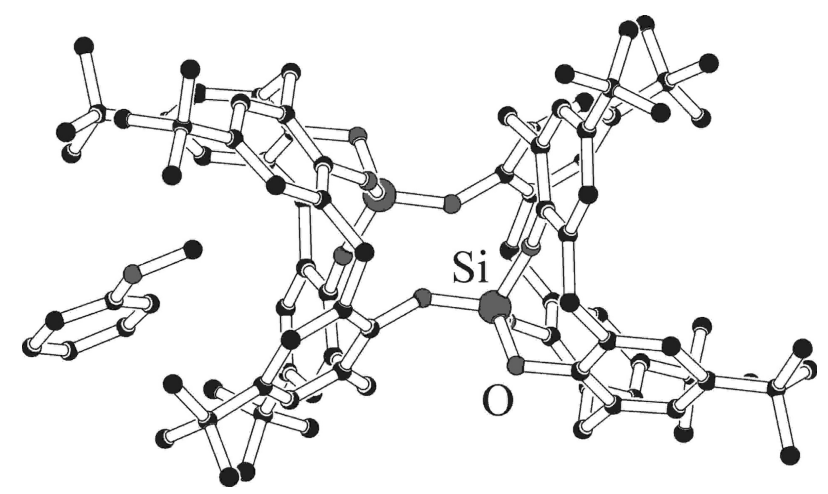

Figure I-8. Structure TAYJOS [7]

There are also two structures which contain two calixarene units covalently connected by one phenolic oxygen atom substituent of their lower rims. Both these structures have empty cavities and belong to 'cluster' $8-\mathrm{V}$.

There is a large number of structures with $\delta>20^{\circ}$ in this group (49\%). All lower rim single atom 'triple-bridged' structures have increased $\boldsymbol{\delta}$ which is probably imposed by the rigid nonsymmetrical bridge. Weak inter- and/or intramolecular interactions $(\mathrm{CH}-\pi ; \pi, \pi-)$ combined with less symmetrical substitution are behind increased $\delta$ in the rest of the structures.

Uncomplexed calix[4]arene molecules belonging to less symmetrical substitution patterns (70 cif files) are discussed in the Supplementary Materials.

\section{Heteroatom-bridged cone calix[4] arenes}

The group of cone heteroatom-bridged calix[4]arenes comprises of 115 cif files containing 137 independent molecules; symmetrically tetrasubstituted structures form more than $77 \%$ of these hits (Table 3). The number of complexes in this group is relatively large (50 cif files with 66 independent molecules); one of the reasons being probably easy coordination on the heteroatom bridges. The vast majority of these complexes ( 3 exceptions only) belong to the symmetrically tetrasubstituted group. The only bridge groups that 
occur in this group are $\mathrm{S}$, SO (four structures) and $\mathrm{SO}_{2}$ (seven structures). All structures containing other bridge than $\mathrm{S}$ are symmetrically tetrasubstituted; these structures are emphasized in text.

The $\alpha-\beta$ plot of the group of cone heteroatom-bridged calix[4]arenes is depicted in Figure 20. The $\alpha-\delta$ plot is depicted in Fig. S-16 in the Supplementary Materials. Complexes are denoted by hollow symbols in these plots (since there are relatively few hits in this group, complexes are not depicted separately).

From the $\alpha-\beta$ plot (Fig. 20), separation of the hits into two distinct groups can be observed. The group at lower $\alpha$ and $\beta$ consists almost entirely of symmetrically tetrasubstituted structures whereas the one at higher $\alpha$ and $\beta$ contains all uncomplexed lower rim distally and proximally substituted structures along with some symmetrically tetrasubstituted ones.

The groups of lower rim distally and proximally substituted structures differ significantly in the $\delta$ parameter which can be observed on the $\alpha-\delta$ plot (Fig. S-16 in the Supplementary Materials). This plot is otherwise not informative.

Since the bonds C-heteroatom in bridges are usually longer than $\mathrm{C}-\mathrm{C}$ bonds in the methylene-bridged group, the cavity of heteroatom-bridged calix[4]arenes is accordingly larger which is reflected in bigger flexibility of the calixarene base frame. The bigger flexibility of heteroatom-bridged calix[4]arenes is confirmed by wider range of parameters $\boldsymbol{\alpha}, \boldsymbol{\beta}$ (especially $\boldsymbol{\alpha}$ ) compared to the methylene-bridged group (see Fig. 20).

The role of the $\delta$ parameter is not so transparent; as in the methylene-bridged structures, this parameter tends to reflect weak inter- and intramolecular interactions present in the structure and is therefore more difficult to interprete. In the following text, this parameter will not be taken into account unless a clear correlation between $\boldsymbol{\delta}$ and a structural effect is found.

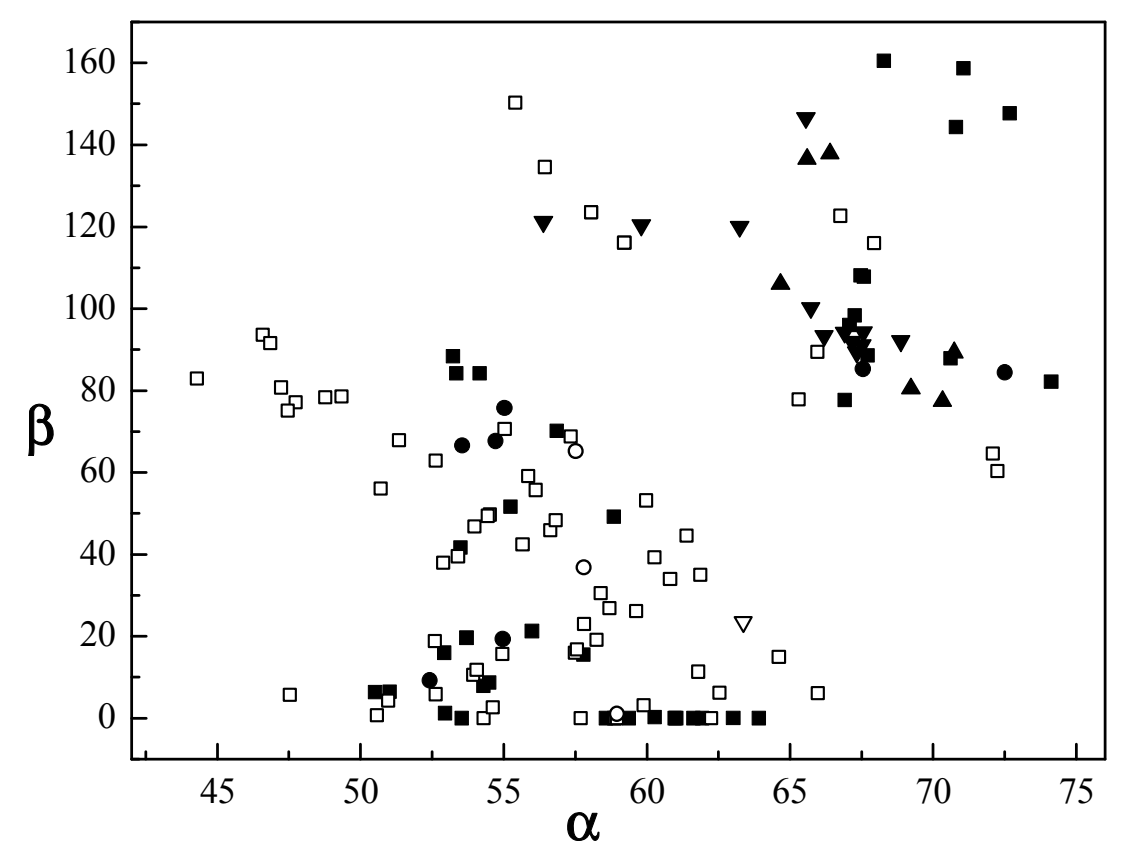

- $\square$ - symmetrically tetrasubstituted; $\boldsymbol{\nabla}$ — distally substituted lower rim, symmetrically tetrasubstituted upper rim; $\mathbf{\Delta} \Delta$ - proximally substituted lower rim, symmetrically tetrasubstituted upper rim; $\bullet \circ-$ other substitution patterns; uncomplexed structures have solid symbols, complexes have hollow symbols

Figure 20. The $\alpha-\beta$ plot of the group of cone heteroatom-bridged calix[4]arenes

As in the group of the methylene-bridged structures, the role of upper/lower rim substitution of the calix[4]arene skeleton and the role of a filled/empty cavity can be evaluated. Figures 21,22 depict the $\alpha-\beta$ plots of all cone heteroatom-bridged calix[4]arenes in dependence on these effects. 


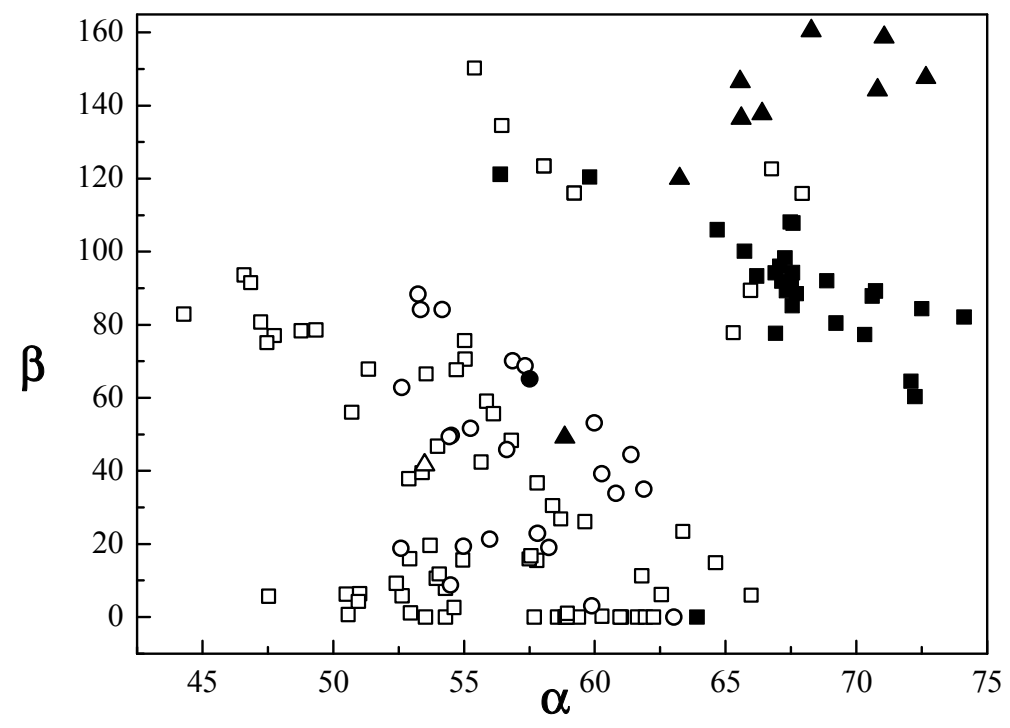

$\square$ - nonpolar upper rim substituent, unsubstituted lower rim hydroxyl groups; ○ — polar upper rim substituent, unsubstituted lower rim; $\Delta$ - unsubstituted upper rim, unsubstituted lower rim; - - nonpolar upper rim substituent, substituted lower rim hydroxyl groups; - — polar upper rim substituent, substituted lower rim hydroxyl groups;

$\Delta$ - no upper rim substituent, substituted lower rim hydroxyl groups

Figure 21. The dependence of the symmetry on the substitution of the calix[4] arene scaffold

As can be seen from Figure 21, structures which retain some hydroxyl groups at the lower rim tend to be closer to $\mathrm{C}_{4 \mathrm{v}}$ geometry than those with these groups alkylated or acylated exactly as in the case of their methylene-bridged counterparts (Fig. 9). Structures with lower rim unsubstituted hydroxyl groups and $\beta \sim 80^{\circ}$ have these groups deprotonated and the stabilizing cyclic array of hydrogen bonds at the lower rim therefore nonexistent. Also, upper rim unsubstituted structures tend to reach higher $\beta$ values than upper rim substituted ones because the $\pi, \pi$-interaction between two calixarene opposite phenyl rings is unhindered in this case (exactly as in the methylene-bridged structures). When compared to a similar plot for cone methylene-bridged calix[4]arenes, the bigger flexibility of heteroatom-bridged structures is confirmed.

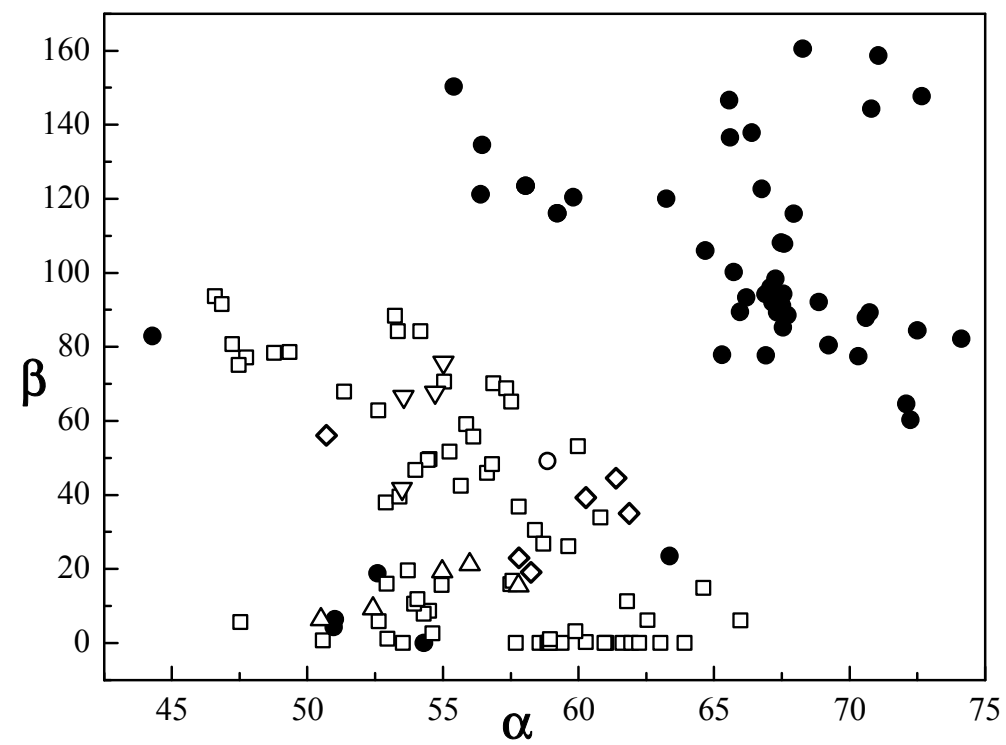

- - no molecule inside the cavity; $\square$ - solvent molecule inside the calixarene cavity;

$\circ$ - lower rim substituent inside the calixarene cavity; $\Delta$ - upper rim substituent inside the calixarene cavity;

- unsubstituted upper rim from another calixarene molecule inside the cavity;

$\diamond$ - ligand from a complex inside the calix[4]arene cavity)

Figure 22. The dependence of the symmetry of the calix[4]arene scaffold on the effect of a filled/empty cavity 
When compared to similar plot for the methylene-bridged cone structures (Fig. 10), it can be seen that these plots convey essentially the same information.

Next part of this chapter deals with the symmetry of the calix[4]arene base frame and the effects which cause its deformation. Since coordination can have a profound effect on the geometry of the calix[4]arene scaffold, complexes are discussed in a separate chapter.

\section{Uncomplexed symmetrically tetrasubstituted heteroatom-bridged calix[4]arenes}

There are two distinct groups of symmetrically tetrasubstituted uncomplexed structures in Figure 20 with $\alpha<65^{\circ}$ : 'cluster' 20 -I with $\beta<30^{\circ}$ and 'cluster' 20 -II with $\beta>40^{\circ}$.

'Cluster' 20-I contains 21 cif files with 21 independent molecules, is centered at $[57.65 ; 4.90 ; 8.34]$ with a standard deviation of $[4.21 ; 7.06 ; 11.34]$. For the most part, these structures are clathrates of $5,11,17,23-$ tetrakis(t-butyl)-25,26,27,28-tetrahydroxy-2,8,14,20-tetrathiacalix[4]arene with various solvents (14 cif files). Clathrates with small symmetrical solvent molecules which have at least $C_{3}$ axis possess $C_{4 v}$ geometry. Larger and less symmetrical clathrate molecules such as 1,2-dichloroethane tend to produce slightly deformed calixarene base frames. Some of these molecules contain a disordered solvent molecule inside the calixarene cavity; since the cavity in these cases is $\mathrm{C}_{4 \mathrm{v}}$-symmetrical $\left(\boldsymbol{\beta}, \boldsymbol{\delta}=0^{\circ}\right)$, we consider the disorder be dynamic (see clathrates of 5,11,17,23-tetrakis(t-butyl)-25,26,27,28-tetrahydroxycalix[4]arene). Representative example is structure QIKSUY [7] (see Fig. I-17).

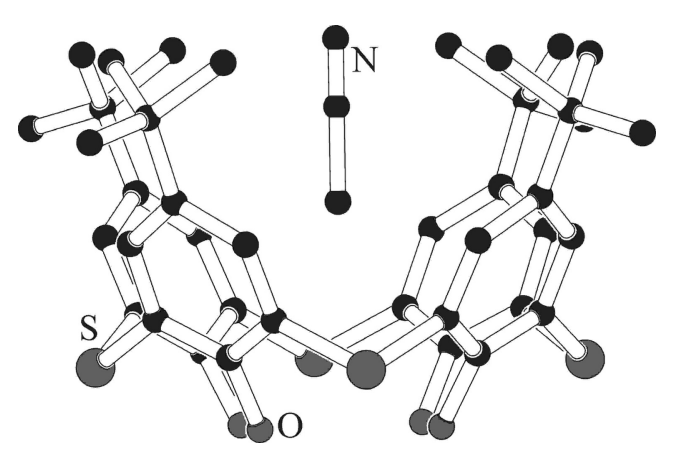

Figure I-17. Structure QIKSUY [7]

Apart from large, nonsymmetrical clathrate molecules, there is another possible type of deformation of the base 5,11,17,23-tetrakis( $t$-butyl)-25,26,27,28-tetrahydroxy-2,8,14,20-tetrathiacalix[4]arene skeleton: deprotonation. Monoanions of this calixarene (e.g. TETNAH [7]) have slightly increased $\delta\left(18-38^{\circ}\right)$ probably because of different arrangement of hydrogen bonds at the lower rim hydroxyl groups (see Fig. I-18). Similar effect has been already observed within the methylene-bridged group.

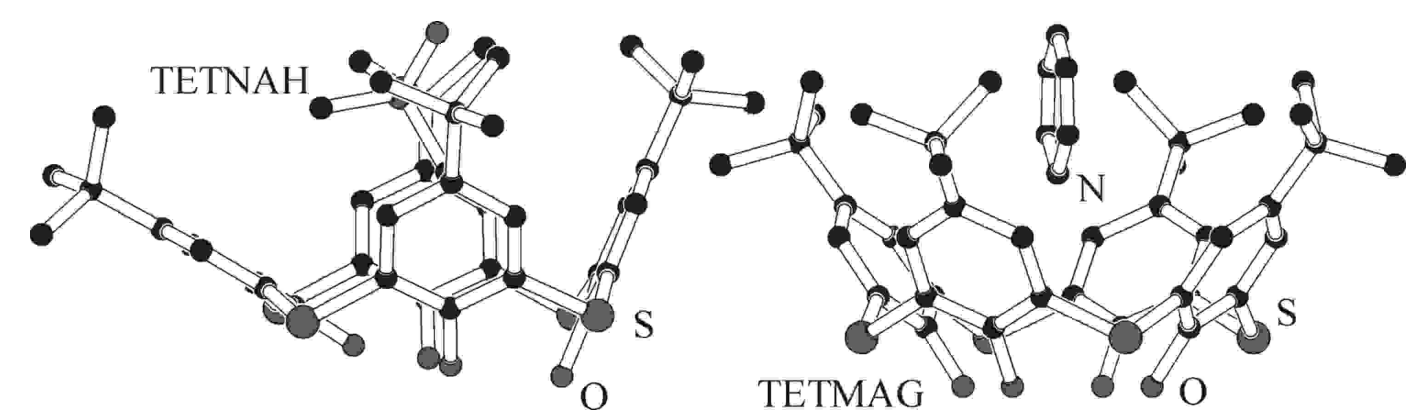

Figure I-18. Structures of monoanion TETNAH and completely protonated TETMAG [7]

Absence of any clathrate molecule inside the 5,11,17,23-tetrakis(t-butyl)-25,26,27,28-tetrahydroxy2,8,14,20-tetrathiacalix[4]arene cavity does not have almost any effect on the symmetry of the calixarene scaffold thanks to a presence of a cyclic array of hydrogen bonds at the lower rim; slight deformation in $\delta$ parameter of the base skeleton in this case is caused by intermolecular $\mathrm{CH}-\pi$ interactions between calixarene molecules. 
Another class of molecules with $\mathrm{C}_{4 \mathrm{v}}$ symmetry are clathrates of 5,11,17,23-tetra-sulfonato-25,26,27,28tetrahydroxy-2,8,14,20-tetrathiacalix[4]arene. Small and symmetrical clathrate molecules tend to produce more symmetrical calixarene base frames (two structures) whereas large and flat aromatic clathrate molecules usually result in a $\boldsymbol{\beta}$ - and $\boldsymbol{\delta}$-deformation of the calixarene scaffold; such structures belong to 'cluster' 20 -II (see similar effect in the group of cone symmetrically tetrasubstituted methylene-bridged calix[4]arenes).

In the case of long upper rim aromatic pendant arms, one of them can reach into the cavity of another calix[4]arene and form a 'clathrate'. The result is a slightly deformed $\mathrm{C}_{4 \mathrm{v}}$ conformation (structure VATJEG [7], Fig. I-19).

Bulky upper rim substituents (e.g. adamantyl) result in more open cavities with $\alpha \sim 52^{\circ}$ (the average $\alpha$ for cone heteroatom-bridged calix[4]arenes is $59^{\circ}$, see Table 4 ), the cause being probably sterical hindrance at the upper rim.

Since all above-mentioned structures in this group contain unsubstituted lower rim hydroxyl groups and therefore a cyclic array of hydrogen bonds at the lower rim, it is no surprise that the calixarene base frame has geometry close to $\mathrm{C}_{4 \mathrm{v}}$ which is unaffected even when no solvent clathrate molecule is present. Deformations to this conformation caused by weak intermolecular interactions or large unsymmetrical clathrate molecules are usually slight; more profound changes can be achieved by affecting the cyclic array of lower rim hydrogen bonds, e.g. by partial deprotonation.

The only structure with alkylated lower rim hydroxyl groups in 'cluster' 20-I is structure MAZNEG(01). The $\mathrm{C}_{4 \mathrm{v}}$ symmetry of the calixarene scaffold is probably caused by presence of solvate acetonitrile molecule inside the calixarene cavity. This structure contains four SO bridges, all oxygen atoms are arranged in equatorial positions with regard to the macrocycle.

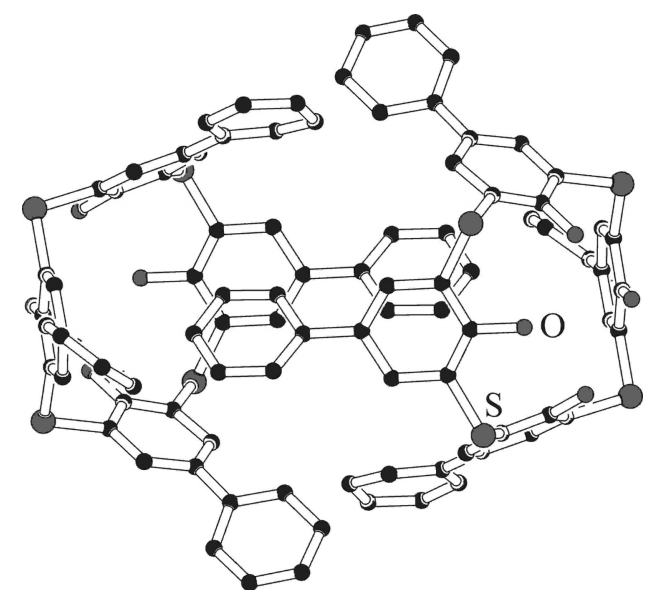

Figure I-19. Structure VATJEG [7]

'Cluster' 20-II contains 6 cif files with 7 independent molecules, is centered at $[55.02 ; 67.05 ; 22.56]$ with a standard deviation of $[1.97 ; 17.95 ; 15.02]$. This group mostly contains clathrates of $5,11,17,23-$ tetrasulfonato-25,26,27,28-tetrahydroxy-2,8,14,20-tetrathiacalix[4]-arene with large aromatic molecules (see above). Representative example of this group is structure FAZYAH [7], very large solvent molecule causes big deformation observable even in $\boldsymbol{\delta}$ parameter (Fig. I-20).

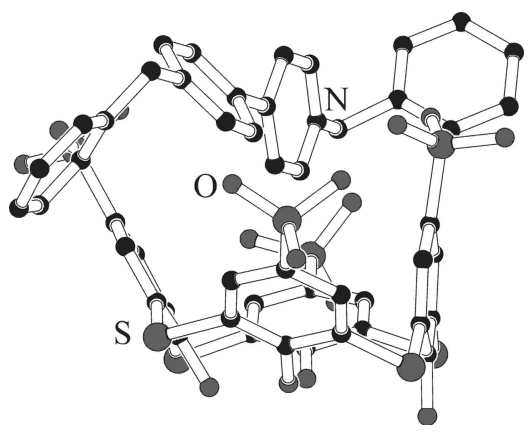

Figure I-20. Structure FAZYAH [7] 
There are two distinct groups of symmetrically tetrasubstituted uncomplexed structures in Figure 20 with $\alpha>65^{\circ}$ : 'cluster' 20 -III with $\beta<110^{\circ}$ and 'cluster' 20 -IV with $\beta>140^{\circ}$.

'Cluster' 20-III contains 8 cif files with 8 independent molecules, is centered at $[68.59 ; 93.32 ; 8.94]$ with a standard deviation of $[2.36 ; 10.51 ; 9.89]$. This group contains upper rim $t$-butyl-substituted structures with alkylated lower rim hydroxyl groups and empty cavity. Empty cavity enables energetically favorable $\pi, \pi$-interaction between two opposite calix[4]arene phenyl rings; relatively bulky $t$-butyl groups at the upper rim of all these structures do not allow the opposite rings to come to close proximity and the $\beta$ parameter is therefore somewhat lower than in structures of 'cluster' 20-IV.

There is one SO-bridged structure in this group (LUXYAE [7]). All oxygen atoms are again in equatorial positions with regard to the macrocycle.

'Cluster' 20-IV contains 3 cif files with 4 independent molecules, is centered at $[70.70 ; 152.77 ; 10.93]$ with a standard deviation of $[1.57 ; 6.94 ; 11.41]$. As in 'cluster' 20 -III, these structures have substituted lower rim hydroxyl groups and no solvent inside the calix[4]arene cavity; however, molecules from 'cluster' 20-III have $t$-butyl at the upper rim whereas molecules from 'cluster' 20-IV have unsubstituted upper rim. No sterical hindrance at the upper rim in the second case allows the opposite phenyl rings to come to close proximity and the parameter $\beta$ is therefore larger. Representative examples of 'clusters' 20 -III and 20-IV are depicted in Fig. I-21.

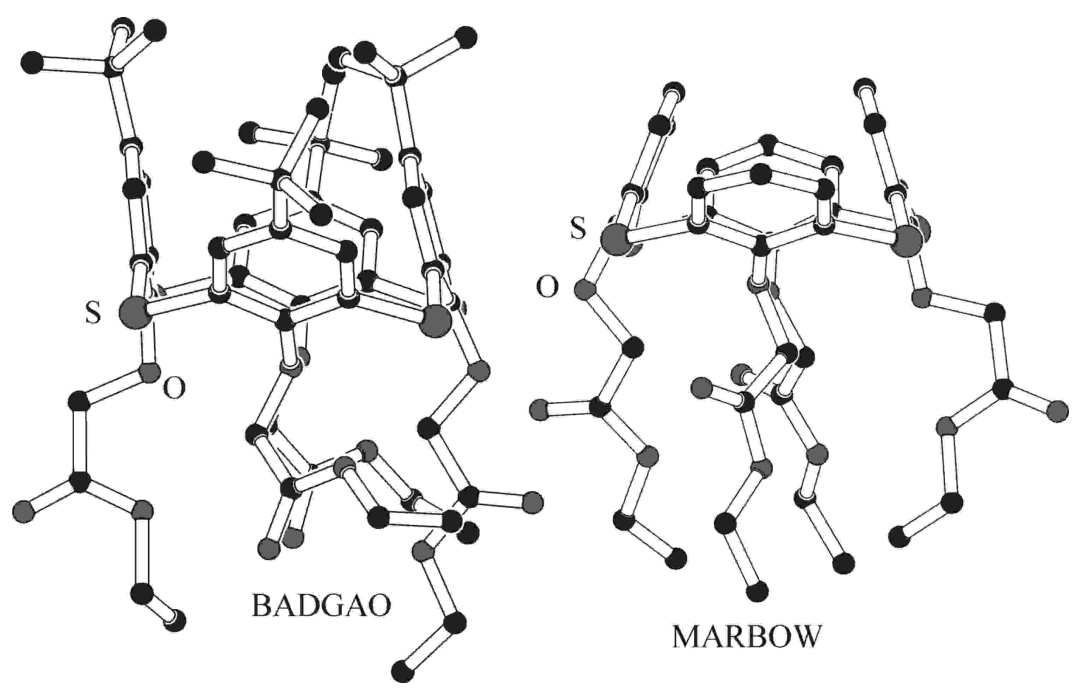

Figure I-21. Structures BADGAO, MARBOW [7]

\section{Uncomplexed lower rim distally substituted heteroatom-bridged calix[4]arenes}

All lower rim distally substituted uncomplexed calix[4]arenes with symmetrically tetrasubstituted upper rim (11 cif files, 13 independent molecules) belong to the group at higher $\alpha$ and $\beta$ in Figure 20. These structures form a diffuse group in Fig. 20 ('cluster' $20-\mathrm{V}$, centered at $[65.37 ; 103.76 ; 28.50]$, standard deviation $[3.43 ; 16.91 ; 14.06])$. The calix[4]arene cavities in all these structures are empty; all structures have hydrogen atoms or $t$-butyl groups at the upper rim; upper rim unsubstituted molecules tend to have larger $\beta$ than upper rim $t$-butyl substituted molecules (the same reasons as for symmetrically tetrasubstituted molecules). Moreover, all structures have the bulkier lower rim substituents at the closer pair of the calixarene opposite phenyl rings which minimizes sterical hindrance at the lower rim. Since there are only a few structures in this group, no correlation between the parameters $\alpha, \beta, \delta$ and type of the lower rim substituent was found; likewise, no correlation between parameter $\beta$ and the number of remaining hydroxyl groups (two or none) at the lower rim as in the methylene-bridged group was observed.

\section{Uncomplexed lower rim proximally substituted heteroatom-bridged calix[4] arenes}

Lower rim proximally substituted structures have $\alpha>65^{\circ}$ and $\beta>75^{\circ}$ and form a diffuse 'cluster' 20-VI in Fig. 20, centered at $[67.82 ; 104.57 ; 7.44]$ with standard deviation $[2.37 ; 24.77 ; 2.33]$ (5 cif files containing 6 independent molecules). All structures in this group contain twice proximally bridged lower rim. All of them have also empty cavities and $t$-butyl groups at the upper rim; only structure QEXLUA [7] has 
unsubstituted upper rim in this group (see Fig. I-22). The value of the $\beta$ parameter is influenced by these effects just as in the previous cases; however, dependence on the length of the proximal bridge was also observed.

Structures with very short proximal bridge have lower $\alpha$ (short proximal bridge forces the structure more open in $\mathrm{C}_{2 \mathrm{v}}$ symmetry); structures with very long bridges have larger $\alpha$ because of sterical hindrance caused by large substituents at the lower rim and therefore more closed cavity. Short bridge also causes marked deformation in the $\beta$ parameter; deformation to $\mathrm{C}_{2 \mathrm{v}}$ geometry is further enhanced by the presence of $\pi, \pi$-stacking between the calixarene opposite phenyl rings. Upper rim $t$-butyl-substituted structure QEXLIO [7] displays lower $\beta\left(106^{\circ}\right)$ than its upper rim unsubstituted counterpart (QEXLUA, $\sim 135^{\circ}$ ) as discussed earlier.

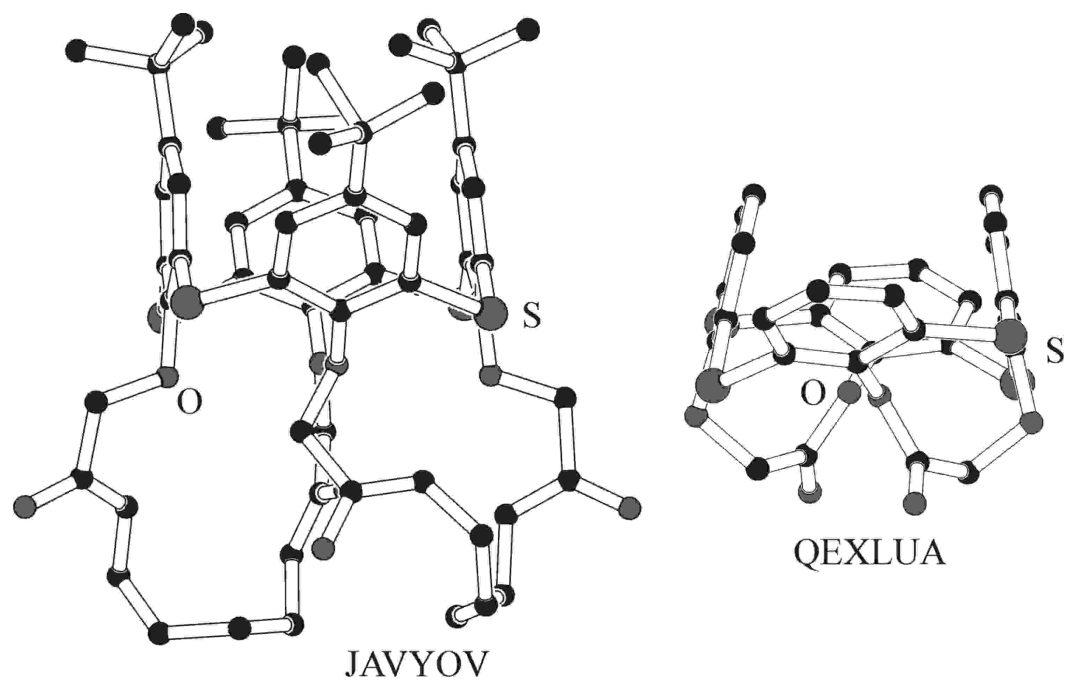

Figure I-22. Structures QEXLUA, JAVYOV [7]

Since other substitution patterns contain only a few structures each, they are not explicitely discussed.

Conclusion

The utility of parameters $\boldsymbol{\alpha}, \boldsymbol{\beta}, \boldsymbol{\delta}$ in describing the conformation of cone calix[4]arenes and the impact of inter/intramolecular interactions present in the structure on the symmetry of the cone calix[4]arene base frame has been evaluated.

Structures with $\mathrm{C}_{4 \mathrm{v}}$ symmetry in the cone group have both $\beta$ and $\delta$ close to $0^{\circ}$. With deformation of the calix[4]arene scaffold symmetry towards $C_{2 \mathrm{v}}$ (flattened cone structures), the $\beta$ parameter increases. Deformation towards $C_{s}$ symmetry is best reflected by increase of the parameter $\delta$. Parameter $\alpha$ reflects the degree of 'opening' of the calix[4]arene cavity; structures with four $\mathrm{OH}$ groups at the lower rim tend to have lower $\alpha$ and therefore more open structure. The arrangement of four hydrogen bonds at the lower rim may have some impact on this behavior; the four hydrogen bonds may cause the lower rim phenolic oxygen atoms come closer to each other and therefore the cavity is more open. On the other hand, in structures with alkylated or acylated lower rim a certain degree of sterical hindrance at the lower rim is present; the lower rim phenolic oxygen atoms therefore tend to „keep distance» from each other and the cavity is more closed. Structures with alkylated or acylated lower rim have therefore bigger $\alpha$.

Among uncomplexed symmetrically tetrasubstituted structures in the methylene-bridged calix[4]arenes, the $\mathrm{C}_{4 \mathrm{v}}$-symmetrical molecules are those with unsubstituted lower rim hydroxyl groups (stabilizing effect of a cyclic array of hydrogen bonds at the lower rim), bulky nonpolar upper rim substituents (such as $t$-butyl; sterical hindrance at the upper rim) and cavity filled by small, symmetrical solvent molecules. Alkylation of all four lower rim hydroxyl groups, removal of $t$-butyl groups from the upper rim, introduction of polar groups to the upper rim, large (especially aromatic) clathrate molecules or missing clathrate molecules (empty cavity) all contribute to deformation towards $\mathrm{C}_{2 \mathrm{v}}$ geometry which is reflected by higher $\beta$.

Among the less symmetrically substituted uncomplexed molecules in the methylene-bridged calix[4]arenes, short distal upper rim bridge, short lower rim proximal bridges and lower rim single atom 'triple 
bridges' are ways how to severely affect the calix[4]arene conformation towards flattened cone $\left(\mathrm{C}_{2 \mathrm{v}^{-}}\right.$ deformed) geometry and, at the same time, to prepare rigid structures.

Cone calix[4]arenes with heteroatom bridges that possess unsubstituted hydroxyl groups at the lower rim tend to have symmetrical $\mathrm{C}_{4 \mathrm{v}}$ conformation thanks to energetically favorable cyclic array of hydrogen bonds. Alkylation or acylation of these groups usually leads to a calix[4] arene scaffold deformed towards $\mathrm{C}_{2 \mathrm{v}}$ symmetry (see similar effects in the methylene-bridged group).

To sum up, when the lower rim phenolic oxygen atoms are substituted and thus energetically favorable array of hydrogen bonds thus disrupted deformation towards $\mathrm{C}_{2 \mathrm{v}}$ symmetry becomes much more feasible. Clathrates usually display more symmetrical arrangement of the calix[4]arene base frame whereas empty calixarene cavity enables $\pi, \pi$-interaction between two opposite calix[4] arene rings to come into play and the resulting calix[4] arene conformation is strongly deformed towards $\mathrm{C}_{2 \mathrm{v}}$ symmetry.

Since calix[4]arenes with heteroatom bridges are more conformationally flexible than their methylenebridged counterparts, it is much more difficult to immobilize these molecules in the desired conformation [5]. One possibility to immobilize the calixarene in flattened cone conformation is lower rim double proximal bridge.

The effect of coordination at upper or lower rim substituents on the calixarene geometry will be disscused in the following part of this review.

\section{Acknowledgements}

We thank RNDr. Ivana Císařová, CSc. (Charles University, Faculty of Science, Department of Inorganic Chemistry) for the provision of CSD data. Access to the Cambridge Crystallographic Data Centre was sponsored by the Grant Agency of the Czech Republic (grant No. 203/99/0067).

\section{Supplementary Materials}

The Supplementary Materials to Part I consist of Figures S-1 to S-16 and discussion of the less symmetrical substitution patterns in the methylene-bridged cone calix[4]arenes.

\section{References}

1 Gutsche C.D. Calixarenes: Monographs in Supramolecular Chemistry / Ed. J.F. Stoddart. - Cambridge: The Royal Society of Chemistry, 1989; Gutsche C.D. // Top. Curr. Chem. - 1984. — No. 1. - P. 47; Shinkai S. // Tetrahedron. — 1993. - Vol. 49, No. 40. - P. 8933-8968 (and references therein).

2 Shinkai S., Ikeda A. // Chem. Rev. — 1997. — Vol. 97. — P. 1713-1734 (and references therein).

3 Macrocycle Synthesis / Ed. D. Parker. — New York: Oxford University Press, 1996.

4 König B., Fonseca M.H. // Eur. J. Inorg. Chem. - 2000. - P. 2303-2310; Iki N., Miyano S. // J. Incl. Phenom. Macrocyclic Chem. - 2001. - Vol. 41. - P. 99-105; Takemura H. // J. Incl. Phenom. Macrocyclic Chem. — 2002. — Vol. 42. - P. $169-186$.

5 Lhoták P. // Eur. J. Org. Chem. - 2004. - P. 1675-1692 (and references therein).

6 Beer P.D., Gale P. // Angew. Chem. Int. Ed. - 2001. - Vol. 40. - P. 486-516 (and references therein).

7 CSD Version 2.3.6 (update August 2006). - Cambridge Crystallographic Data Centre (CCDC).

8 Svozil D., Kalina J., Omelka M. and Schneider B. // Nucleic Acids Research. - 2008. — Vol. 36, No. 11. — P. $3690-3706$.

9 Arnaud-Neu F., Collins E.M., Deasy M., Ferguson G., Harris S.J., Kaitner B., Lough A.J., McKervey M.A., Marques E., Ruhl B.L., Schwing-Weill M.J., Sewardt E.M. // J. Am. Chem. Soc. - 1989. - Vol. 111. — P. 8681-8691.

10 Klimentová J., Vojtíšek P. // Materials Struct. — 2005. — No. 12. — P. 151; Klimentová J., Vojtíšek P. // J. Mol. Struct. — 2007. - Vol. 826, No. 1. - P. 48-63.

11 Morohashi N., Narumi F., Iki N., Hattori T., Miyano S. // Chem. Rev. — 2006. — Vol. 106. — P. 5291-5316 (and references therein). 
Я. Климентова, М. Мадлова, П. Немечкова,

Л. Палатинусова, П. Войтишек, И. Лукеш

\title{
Каликс[4]арендердің конформациялары - CSD мәліметтеріне негізделген зерттеу. I-бөлім. Каликс[4]арендердің метилен- және гетероатомды-көпір тәрізді конусты конформерлері
}

\begin{abstract}
Метиленді және гетероатомды көпіршелі каликс[4]арендердің конформациялары Кембридж құрылым банкінің (CSD) мәліметтері негізінде алдын ала енгізілген $\alpha, \beta$ және $\delta$ параметрлері арқылы зерттелді. Бұл параметрлердің жоғарыда көрсетілген қосылыстардың көмірсутекті негізгі құрылымының конформациясын зерттеудегі пайдасы көрсетілді. Құрылысындағы аралық және/немесе молекулаішілік әрекеттесулеріндегі бұл параметрлерінің тәуелділік көрсеткіштері каликс[4]ареннің геометриясының жоғарыда айтылған әсерлерге тәуелділігін анықтау үшін қарастырылды. Конустық топтағы $\mathrm{C}_{4 \mathrm{v}}$ симметриялы құрылыстар $0^{\circ}$ жуық $\beta$ және $\delta$ ие. Каликс[4]арен симметриясының $\mathrm{C}_{2 \mathrm{v}}$ қарай өзгеру кезіңде $\beta$ параметрі жоғарылайды. $\mathrm{C}_{\mathrm{s}}$ симметриясына қатысты өзгеруі $\delta$ параметрлерінің жоғарылауымен айқын байқалады. $\alpha$ параметрі каликс[4]арен қуысының «ашылу» деңгейін көрсетті; төменгі шеңбер бойынша төрт ОН тобы бар құрылыстар төменгі $\alpha$ ие, сәйкесінше, айтарлықтай ашық құрылыста болады.
\end{abstract}

Кілт сөздер: каликс[4]арендер, конформация, торсионды бұрыш, бұрмалану параметрі, молекулаішілік әрекеттесулер.

\author{
Я. Климентова, М. Мадлова, П. Немечкова, \\ Л. Палатинусова, П. Войтишек, И. Лукеш
}

\section{Конформации каликс[4]аренов - исследование, основанное на данных CSD. Часть І. Конусные конформеры метилен- и гетероатом-мостиковых каликс[4]аренов}

Конформации каликс[4]аренов с метиленовыми и гетероатомными мостиками из Кембриджского банка структурных данных (CSD) были исследованы с помощью ранее введенных параметров $\alpha, \beta$ и $\delta$. Была показана полезность этих параметров в описании конформации углеводородной основной структуры для указанных выше соединений. Зависимость значений этих параметров в меж- и/или внутримолекулярных взаимодействиях, присутствующих в структуре, была исследована для того, чтобы выяснить, как геометрия каликс[4]арена зависит от перечисленных выше эффектов. Структуры с $\mathrm{C}_{4 \mathrm{v}}$ симметрией в конической группе имеют и $\beta$, и $\delta$, близкие к $0^{\circ}$. При деформации симметрии каликс[4]арена к $\mathrm{C} 2 \mathrm{v}$ (уплощенных конусных структур) параметр $\beta$ возрастает. Деформация по отношению к симметрии Cs лучше всего отражается с увеличением параметра $\delta$. Параметр $\alpha$ отражает степень «раскрытия» полости каликс[4]арена; структуры с четырьмя группами ОН по нижнему ободу, как правило, имеют более низкую $\alpha$ и, следовательно, более открытую структуру.

Ключевые слова: каликс[4]арены, макромолекулы, конформация, торсионный угол, параметр искажения, внутримолекулярные взаимодействия. 